\title{
Aridification across the Carboniferous-Permian transition in Central equatorial Pangea: the Catalan Pyrenean succession (NE Iberian Peninsula)
}

Eudald Mujal*a, $^{\text {a, }}$, Josep Fortuny ${ }^{\mathrm{b}, \mathrm{c}}$, Josep Marmi $^{\mathrm{b}}$, Jaume Dinarès-Turell ${ }^{\mathrm{d}}$, Arnau Bolet ${ }^{\mathrm{b}}$, Oriol Oms ${ }^{\mathrm{a}}$

a Departament de Geologia, Universitat Autònoma de Barcelona, E-08193 Bellaterra, Spain.e-mail addresses: eudald.mujal@gmail.com, joseporiol.oms@uab.cat

b Institut Català de Paleontologia Miquel Crusafont, ICTA-ICP building, c/ de les columnes, s/n, E-08193 Cerdanyola del Vallès, Spain. e-mail addresses: josep.fortuny@icp.cat, josep.marmi@icp.cat, arnau.bolet@icp.cat

c Centre de Recherches en Paléobiodiversité et Paléoenvironnements, UMR 7202 CNRS-MNHN-UPMC, Muséum national d'Histoire naturelle, 8 rue Buffon, CP38, F75005 Paris, France.

${ }^{\mathrm{d}}$ Istituto Nazionale di Geofisica e Vulcanologia, Via di Vigna Murata 605, I-00143 Roma, Italy. e-mail address: jaume.dinares@ingv.it

*Corresponding author: E. Mujal, eudald.mujal@gmail.com

\begin{abstract}
The Carboniferous-Permian terrestrial successions record a global climatic shift from icehouse to hothouse conditions. Our multidisciplinary study documents an aridification trend throughout the $\sim 1000 \mathrm{~m}$ thick composite terrestrial succession of the western Catalan Pyrenees (NE Iberian Peninsula), representing this time period. The detailed stratigraphic framework integrates sedimentology, paleopedology, biochronology (plant
\end{abstract}


fossils and tetrapod footprints) and geochronology (paleomagnetism). Additional absolute age correlation is also carried out. The new and reviewed data show that the late Carboniferous wet environments (with short drought periods) progressively changed to a strong seasonal semi-arid and arid climate (with short humid periods) through the early Permian. This paleoclimatic trend supports the previously suggested aridification of the Pangean pan-tropical belt, and supports the hypothesis of the influence of the recurrent climatic fluctuations in Central Pangea, being tentatively correlated to the Southern Gondwanan glaciation-deglaciation periods. Therefore, the Carboniferous-Permian terrestrial succession from the Catalan Pyrenees emerges as a continuous record that can help to constrain late Paleozoic paleoenvironmental events.

\section{Keywords}

Carboniferous-Permian transition; paleosols; biostratigraphy; paleoclimate; Pyrenean Basin; Western Tethys.

\section{Introduction}

The Carboniferous-Permian (C-P) transition is characterized by global aridification, with recurrent warming-cooling fluctuations that coincided with the end of the late Paleozoic ice age (LPIA) (Fielding et al., 2008) and the formation of Pangea (Tabor and Poulsen, 2008; Montañez and Poulsen, 2013). This icehouse-greenhouse transition was driven by an increase of atmospheric $p \mathrm{CO}_{2}$ (with associated fluctuations) resulting in a global warming (Montañez et al., 2007, 2016; Peyser and Poulsen, 2008; Isbell et al., 2012) and being an important analogue for the Pleistocene-present climatic 
change (DiMichele et al., 2001; Chumakov and Zharkov, 2002; Tabor and Poulsen, 2008; Tabor et al., 2013; DiMichele, 2014; Montañez et al., 2016).

Paleoenvironmental and paleoclimatic trends across $\mathrm{C}-\mathrm{P}$ terrestrial successions are well-constrained in many areas of western equatorial and tropical Pangea (e.g., Tabor and Montañez, 2002, 2004; DiMichele et al., 2006, 2009; Falcon-Lang et al., 2006; Tabor et al., 2008, 2013; DiMichele, 2014). By contrast, few regions have been analyzed in equivalent latitudes from Central Pangea. Such regions include central and eastern Europe (Roscher and Schneider, 2006; Eros et al., 2012; Opluštil et al., 2013, 2017a) and the French Lodève Basin (Schneider et al., 2006; Lopez et al., 2008; Michel et al., 2015, 2016). In fact, C-P terrestrial successions of southwestern Europe (Western Tethys or eastern equatorial Euramerica) are mostly characterized by large stratigraphic hiatuses, both due to erosion and/or lack of sedimentation (Cassinis et al., 2013; Gretter et al., 2015). Nevertheless, some regions record relatively long and continuous successions, such as the case here studied.

We analyze a $\sim 1000 \mathrm{~m}$ thick composite terrestrial succession, including newly reported sites, from the Catalan Pyrenees (NE Iberian Peninsula). Our goals are: (1) to provide a detailed stratigraphic framework of the $\mathrm{C}-\mathrm{P}$ transition in order to (2) discuss the paleoenvironmental and pedotype evolution, (3) allocate the paleontological (plant megafossils and tetrapod footprints) and paleomagnetic data, reviewing and constraining the bio- and magnetostratigraphy, and (4) unravel the paleoclimatic trends across the studied succession, correlating it to the global record. The expanded and continuous record throughout the Pyrenean C-P succession sheds light on the imprint of the recurrent climatic fluctuations in Central equatorial Pangea.

\section{Geological setting}


The late Paleozoic-early Mesozoic Catalan Pyrenean deposits crop out discontinuously in a narrow E-W oriented belt, with strata generally dipping southwards due to the Mesozoic-Cenozoic Alpine orogeny (Fig. 1A). During the late Paleozoic, the collision of Gondwana and Laurussia landmasses resulted in the equatorial Variscan orogenic belt (Pereira et al., 2014). At the southern margin of the Variscan mountains in Central equatorial Pangea (Western Tethys margin), the Pyrenean region (NE Iberian microplate) displayed several continental depocenters of half-graben geometry and bounded by strike-slip faults derived from a dextral-transpression tectonic activity (in the whole the Pyrenean rift system, divided in sub-basins; Gisbert, 1981; Speksnijder, 1985; Saura and Teixell, 2006; Gretter et al., 2015). The infilling of such depocenters started in the late Carboniferous and persisted until the Middle Triassic marine transgression (Mujal et al., 2017). Overlying the Cambro-Ordovician and Devonian basement, the lowermost Carboniferous deposits are the result of an intense volcanic activity that generated rhyodacitic pyroclastic tuffs and andesitic lavas (Martí, 1983).

The study area is placed at the Erillcastell-Estac sub-basin, at the westernmost part of the Catalan Pyrenees (Fig. 1A). In this sub-basin, the basal Carboniferous volcanic sequences (lower portion of the Grey Unit) are conformably overlaid by grey to green volcanic and fluvio-lacustrine deposits (upper portion of the Grey Unit, and Transition Unit), which mostly resulted from the erosion and dismantling of the Carboniferous volcanic sequences (Nagtegaal, 1969). These volcanic and fluviolacustrine deposits are conformably overlaid by volcanosedimentary and alluvial redbeds (Lower Red Unit) (Nagtegaal, 1969; Martí, 1996). The grey to green and red-bed deposits analyzed build up a $\sim 1000$ m thick continuous sequence. Strata dip southwards $\left(183^{\circ} \mathrm{N}\right.$ to $228^{\circ} \mathrm{N}$ ), with inclinations ranging from $60^{\circ}$ (grey-beds) to $80^{\circ}-90^{\circ}$ (red-beds) 
(Fig. 1B). The red-beds are unconformably overlaid by the Triassic Buntsandstein facies (Mujal et al., 2017) (Figs. 1B, 2). On the one hand, the grey to green beds have been attributed to the late Carboniferous-earliest Permian (Stephanian C-“Autunian") based on plant fossil content (Broutin and Gisbert, 1985; Talens and Wagner, 1995; Wagner and Álvarez-Vázquez, 2010; here reviewed through the study of a newly reported plant fossil-site). On the other hand, the red beds have been attributed to the middle-late early Permian (Artinskian) by means of tetrapod ichnotaxa (Mujal et al., 2016a). Furthermore, Pereira et al. (2014) dated igneous rocks from different Pyrenean subbasins, constraining the Permo-Carboniferous magmatic cycles from ca. $307 \mathrm{Ma}$ to ca. 266 Ma. The regional stratigraphic units here used (Fig. 2) are based on those defined by Gisbert (1981). Their equivalent nomenclatures (Mey et al., 1968; Nagtegaal, 1969) are synthesized by Mujal et al. (2016b, their Fig. 2B).

\section{Material and methods}

Two different areas, Coll de Sas and Les Esglésies (both from the Pallars Jussà region, Catalonia, NE Iberian Peninsula), were analyzed. A detailed geological map (Fig. 1B) was produced based on field-tracking of strata, photointerpretation and a revision of previous regional maps (Hartevelt, 1970; Saura and Teixell, 2006). Two main stratigraphic sections were measured, one in each locality (coordinates in WGS84), by means of a Jacobs staff and a meter: the stratigraphically lower section is Coll de Sas ( 134 m thick; base, 42²4'33.05' 'N 0'50'40.74'’E; top, 42’24'31.03'’N, $0^{\circ} 50^{\prime} 36.96$ ' $\left.\mathrm{E}\right)$ the stratigraphically upper section is Les Esglésies ( $~ 840 \mathrm{~m}$ thick; base, $42^{\circ} 24^{\prime} 6.34^{\prime \prime} \mathrm{N} \quad 0^{\circ} 52^{\prime} 4.87^{\prime \prime} \mathrm{E} ; \quad$ top, $\left.\quad 42^{\circ} 23^{\prime} 30.91^{\prime}{ }^{\prime} \mathrm{N} \quad 0^{\circ} 52^{\prime} 20.64{ }^{\prime \prime} \mathrm{E}\right) \quad$ (Fig. 2; Supplementary Data S1, S2). 
Sedimentological analyses are mainly based on macroscopic features, including: strata thickness and geometry, strata relationship (both laterally and vertically), rock composition and color, grain size, and sedimentary structures. Our results are further compared with those from nearby and equivalent localities (Nagtegaal, 1969; Besly and Collinson, 1991; Gretter et al., 2015; Mujal et al., 2016a). Our sedimentological interpretations follow the reference works by Miall $(1985,1992)$ and Gretter et al. (2015). Furthermore, we coupled our results with the fluvial facies classification of Gretter et al. (2015), which is summarized in Supplementary Table S1. Volcaniclastic rocks are classified and interpreted following Branney and Kokelaar (2002) and further compared with the classification by Martí (1996).

Identification and interpretation of paleosols are classified after Mack et al. (1993), with additional remarks from further works cited throughout the text. The USDA Soil Taxonomy system (Soil Survey Staff, 2014) is used to define horizons (O, A, B, C and suffixes). Carbonate pedotypes are also classified following Gile et al. (1966) and Machette (1985) (Stages I-VI). Paleosol identifications and derived paleoclimatic interpretations are compared and coupled with data from Gascón and Gisbert (1987) and Aso et al. (1992). Our paleopedological results and interpretations, as well as horizon codes, are summarized in Supplementary Table S2.

The Coll de Sas locality was systematically excavated to recover plant fossils, resulting in a collection of 99 sacks (mean weight of $\sim 2 \mathrm{~kg} / \mathrm{sack}$ ) distributed along 33 levels of the measured section. Additionally, 9 levels bearing plant fossils from two complementary sections, located at the ESE and the W from the main Coll de Sas section, were also excavated (Supplementary Fig. S1) (see Supplementary Text S1 for the exact stratigraphic position of the excavated levels). The plant fossils collected from the Grey Unit are identified and classified by comparison with previous works (e.g., 
Wagner and Álvarez-Vázquez, 2010; Charbonnier, 2014). The newly plant fossils collected here reported are stored at Institut Català de Paleontologia Miquel Crusafont (Sabadell, Spain) under label IPS, each label is specified in the Supplementary Text S1. Tetrapod footprints from Les Esglésies (from the Lower Red Unit) were analyzed by Voigt and Haubold (2015) and Mujal et al. (2016a). Here we provide additional remarks as well as new footprint-bearing levels identified through the measured section. Sections and sites studied by Mujal et al. (2016a) are correlated to the herein measured section.

Paleomagnetic sampling consisted on hand-oriented blocks collected from 24 stratigraphic levels distributed along the $\sim 134 \mathrm{~m}$ Carboniferous section at Coll de Sas (coded CS). Paleomagnetic core samples from 26 stratigraphic levels were taken with a portable rock coring drill along $750 \mathrm{~m}$ thickness of Permian section at Les Esglésies (coded ES). Samples were subsequently cut in standard paleomagnetic specimens for laboratory analysis. Natural remanent magnetization (NRM) and remanence through demagnetization were measured on a 2 G Enterprises DC SQUID high-resolution passthrough cryogenic magnetometer (manufacturer noise level of 10-12 $\mathrm{Am}^{2}$ ) operated in a shielded room at the Istituto Nazionale di Geofisica e Vulcanologia in Rome, Italy. A Pyrox oven in the shielded room was used for thermal demagnetizations, and alternating field (AF) demagnetization was performed with three orthogonal coils installed in line with the cryogenic magnetometer. Progressive stepwise AF demagnetization was routinely used and applied after a single heating step to $150^{\circ} \mathrm{C}$. AF demagnetization included 14 steps $(4,8,13,17,21,25,30,35,40,45,50,60,80,100 \mathrm{mT})$. Thermal demagnetization included 13 demagnetization steps up to $680^{\circ} \mathrm{C}$. Characteristic remanent magnetizations (ChRM) were computed by least-squares fitting (Kirschvink, 1980) on the orthogonal demagnetization plots (Zijderveld, 1967). The magnetic 
stratigraphy is based on virtual geomagnetic polar (VGP) latitudes, the latitude relative to the mean paleomagnetic pole for the individual section.

\section{The late Carboniferous-early Permian Pyrenean succession: Results and interpretation}

Here we describe and interpret the studied localities, providing new data of the Grey Unit (Figs. 3, 4), Transition Unit (Fig. 5) and Lower Red Unit (Figs. 6-8), and also integrating previous data. We provide a general framework of this terrestrial succession that is discussed in the subsequent section.

\subsection{Stratigraphy and sedimentology}

\subsubsection{Grey Unit succession}

Outcrops of this unit are well exposed at Coll de Sas (Fig. 3). However, the base of the succession is affected by a north-directed inverse fault thrusting over the Triassic Buntsandstein facies (Fig. 1B). This tectonic structure represents the inversion of a normal fault, reactivated during the Alpine orogeny (Saura and Teixell, 2006). As this basal portion is highly tectonized and does not present well-exposed outcrops, it was neither measured nor studied in detail.

The measured section starts with laminated siltstones and very fine-grained sandstones (floodplain and overbank deposits) with accumulations of plant remains. These fine-grained facies are overlain by a $6 \mathrm{~m}$-thick sequence of conglomerates grading to coarse-grained sandstones (Fig. 3B). Conglomerates display erosive bases with flow structures and trough cross stratification; pebbles are large ( $10 \mathrm{~cm}$ diameter $)$ 
and of andesitic composition (Fig. 3B'); the overlying sandstones grading from the conglomerates display planar cross stratification and ripples at the topmost surface. These deposits are interpreted as a multi-storey infilling of fluvial braided channels. They are laterally tracked along the entire outcrop (oriented SE-NW, ca. $400 \mathrm{~m}$ long).

The rest of the Grey Unit, ending at the $44 \mathrm{~m}$ thickness of the measured section, consists of mudstones (both claystones and siltstones), carbonaceous mudstones (i.e., mudstones with a significant content of coal), generally thin $(<50 \mathrm{~cm}$ thick, but up to 2 m thick) coal seams (Fig. 4A; Supplementary Data S1), and fine- to coarse-grained sandstones (Fig. 3A). Carbonaceous mudstones are the most abundant deposits that, together with mudstones and coals, represent laminated floodplain and overbank deposits with abundant plant remains (Fig. 3A, C). Thin sandstone bodies $(10-30 \mathrm{~cm}$ thick) with tabular geometry are often interbedded within mudstones; these deposits correspond to ephemeral floods of the fluvial plain, resulting in overbank and occasional crevasse splay deposits. A distinct interval occurs from 11 to $16 \mathrm{~m}$ of the measured section: these deposits are built up of finely-laminated carbonaceous mudstones rhythmically alternating with thin coal layers. This interval, roughly coarsening upwards, is a lake infilling equivalent to that documented by Besly and Collinson (1991) in westward adjacent areas (Peranera and Erillcastell sites: $2.64 \mathrm{~km}$ and $4.21 \mathrm{~km}$ from Coll de Sas, respectively).

The medium- and fine-grained sandstones are commonly 50-70 cm thick (and up to $1 \mathrm{~m}$ thick) and have a low lateral continuity (extending <4-5 m); they rapidly grade to mudstones and carbonaceous mudstones (Fig. 3C). These sandstone strata are arranged as lateral accretion units that display a vertical thinning- and fining-upwards cycles (Fig. 3C). The sharp basal contact of the cycle contains a lag deposit of gravels, while the lower and upper part of the cycle contain trough cross-stratification and climbing 
ripples, respectively. Lateral accretions and the relatively restricted lateral extent indicate that such sandstones result from the infilling of small meandering fluvial channels (Besly and Collinson, 1991; Gretter et al., 2015). In other cases, sandstones display longitudinal accretions (Fig. 4D) that include downstream cross bedding, indicative of increased stream flow, thus resulting in the formation of sporadic low sinuosity channels. Plant remains preserved in channel fills indicate a relatively low energetic flow (see Section 4.3.1 below). In sum, the uppermost part of the Grey Unit $44 \mathrm{~m}$ in measured section reflects a fining-upwards sequence of a distal alluvial system, reworking volcanic deposits (Nagtegaal, 1969). Such interpretations also agree with those of Besly and Collinson (1991), who observed a rapid lateral change of facies, indicative of short-lived meandering streams.

At Les Esglésies, only a small portion of the GU is exposed ( 12 $\mathrm{m}$ thickness), as the basal inverse fault reaches stratigraphically higher levels than in the Coll de Sas succession. The Grey Unit at Les Esglésies is composed of coarse- to very fine-grained sandstones with interbedded mudstones and thin coal seams; occasional grey, crystalrich (quartz and feldspar crystals few millimeters in dimensions) and thin-layered (around $5 \mathrm{~cm}$ thick) volcanic cinerites (ash falls) occur. Sandstones, the predominant lithology, display lateral accretions; i.e., meandering fluvial channels similar to those from Coll de Sas. Carbonized plant fragments are common in the sandstone deposits. The finely laminated mudstones grade from sandstones and preserve abundant plant fragments. Coal seams often appear within the mudstones and sandstones (Fig. 4B).

Although a general equivalence is observed between Coll de Sas and the westwards Pyrenean successions of Besly and Collinson (1991), some differences exist: Coll de Sas displays a higher proportion of mudstones while sandstone bodies are smaller (both thinner and of less lateral extent) than those of Peranera and Erillcastell. 
Even in the Coll de Sas outcrop (laterally extended $~ 400 \mathrm{~m}$ ), correlation of the three measured sections shows an uneven paleorelief (Fig. S1). This explains differences in grain size proportions between close localities, influenced by intense syn-tectonic and volcanic activities (e.g., Besly and Collinson, 1991; Gretter et al., 2015). Despite this high lateral variation, all Grey Unit localities display equivalent vertical patterns.

The transition to the Transition Unit is mainly characterized by: (1) compositional change of the sandstones, from volcanic litharenite (Grey Unit) to a quartzarenite (Transition Unit); and (2) a depletion of coal, carbonaceous mudstones and plant megafossils from the Grey Unit to the Transition Unit.

\subsubsection{Transition Unit succession}

This unit entirely crops out in Coll de Sas (Supplementary Data S1). Here, the lower half of the Transition Unit (44.0-94.5 m thickness of the main section) consists of green/grey fine- and medium-grained sandstones and mudstones (Fig. 5A). Some sandstone beds display thickness variation and cross stratification, being similar to the lateral accretions observed in meandering fluvial bars. Mudstone floodplain deposits are massive and generally grade from sandstone beds.

From $94.5 \mathrm{~m}$ to $100.6 \mathrm{~m}$ of Coll de Sas section, the Transition Unit is composed of an alternating succession of dolostones and thin laminated coal with interbedded siltstone (Fig. 5H). This distinct interval within the Transition Unit is almost barren, with only unidentifiable scarce and small plant fragments and a possible cylindrical burrow. This succession correspond to lake deposits (Nagtegaal, 1969; see also Valero Garcés, 1993), which would indicate a flooding event within the general desiccation trend of the Transition Unit. 
The uppermost Transition Unit displays laminated sandstone intervals with microbreccia lags (Fig. 5I). At Coll de Sas, the Transition Unit ends at $130.6 \mathrm{~m}$ of the measured section, where the mudstones suddenly change from green to red (top right in Fig. 5F).

At Les Esglésies, the Transition Unit is poorly exposed and affected by local faults. The lowermost part is composed of fining upwards sequences starting with a conglomerate/breccia (at base) and coarse-grained sandstones (the rest) grading to medium-grained sandstones; scarce and carbonized plant fragments are found within all the layers. They are overlain by two thin (15 and $30 \mathrm{~cm}$ thick) micritic limestone layers with dark laminae at the topmost part of each one. These limestone layers are most probably equivalent to the succession of lacustrine dolostone and laminated coal with interbedded siltstone found at 94.1-100.6 m from the Coll de Sas section. The following succession is built up by an alternation of greyish sandstones and mudstones. The subsequent interval (uppermost Transition Unit, from 26 to $42 \mathrm{~m}$ of the measured section) is not fully exposed. Although it is highly affected by local faults, the thickness and general pattern are recognizable. It is mostly composed of laminated mudstones, but also thin (30-50 cm thick) sandstone and microconglomerate layers (Fig. 5J). These coarse layers correlate with those from Coll de Sas. The uppermost Transition Unit is composed of green mudstones that suddenly change to red mudstones corresponding to the base of the Lower Red Unit.

\subsubsection{Lower Red Unit succession}

The Lower Red Unit is a red-bed succession mainly composed by volcaniclastic deposits, but in several intervals such deposits display structures characteristically developed by fluvial processes. 
At Coll de Sas, only the base of the unit was measured, as it is substantially more eroded by the Buntsandstein facies than in Les Esglésies, where the sequence is much thicker (Fig. 1B). At Coll de Sas, the Lower Red Unit consists of red mudstones sharply grading from green ones of the Transition Unit. A 40-cm-thick breccia occurs above the $132 \mathrm{~m}$ of the measured section (Fig. 6A). Breccia clasts are polymictic (composed of quartz, lidite, andesites, sandstone, and limestones). Matrix is poorly cemented, thus the breccia does not project out of the relief. Breccia appears to penetrate the underlying red mudstone (Fig. 6A). All these features are those of ignimbrites with gravitational collapse (Branney and Kokelaar, 2002). This breccia, and others occurring through Les Esglésies section (see below), are therefore interpreted as ignimbrite deposits.

At Les Esglésies, the Lower Red Unit crops out deposits of volcaniclastic (1) and fluvial (2) origin to be distinguished. As explained below, the fluvial deposits result from the reworking of volcaniclastic material.

(1) - Volcaniclastic deposits display grain sizes ranging from mudstones to breccias, but they most commonly are composed of fine- and medium-grained sandstone deposits. These red-beds generally consist of tabular strata. They project out characteristic straight "walls" on the relief (vertical dipping of the strata; Fig. 6B) that are laterally tracked for several kilometers (Fig. 1B) and even along the entire Catalan Pyrenees (Martí, 1996), thus indicating a large lateral extent and a relatively flat contemporary landscape (Nagtegaal, 1969; Martí, 1996). The fine- and medium-grained deposits generally display parallel and/or cross stratification (defined by crystal alignments) and fining-upwards gradation (Fig. 6E), but some beds are also massive. Soft pebbles and lithic fragments commonly occur at the lower portion of the sandstone bodies (Fig. 6E). These deposits correspond to tuff and lapilli-tuff deposits generated by 
pyroclastic flows (the most common facies are mLT, sLT, //sT, xsT of Branney and Kokelaar, 2002). Mudstones are highly laminated, grading from sandstones. Breccias are polymictic and poorly cemented as those from Coll de Sas. Breccia bases are mostly erosive (Fig. 6C), some of them are massive (facies mlBr of Branney and Kokelaar, 2002); other volcanic sandstones and breccias display parallel and cross stratification and imbricated clasts (Fig. 6C), corresponding to fallout and traction flows (facies //blBr and xslBr of Branney and Kokelaar, 2002, respectively). Occasionally, sandgrained volcaniclastic deposits display breccia lenses mostly composed of lithic fragments; they correspond to facies lenslBr of Branney and Kokelaar (2002). Some breccias also contain limestone fragments (Fig. 6D), which correspond to fragments of the underlying (and eroded) calcretes (indurated carbonate horizons; see pedogenic features below). All the above described deposits show different contacts between strata: some of them are sharp and erosive, whereas others are transitional.

Martí and Mitjavila (1988) and Martí (1996) interpreted these red-beds as distal volcaniclastic facies, which could be transported hundreds of kilometers from the emission point, situated in the eastwards Castellar de n'Hug sub-basin. Occasionally, the Les Esglésies section displays distinct grey and green, thin (generally 5-6 cm thick, Fig. 6F; but up to $40-50 \mathrm{~cm}$ thick towards section top, Fig. 6G) and crystal-rich (millimetric quartz and feldspar crystals) volcaniclastic layers of large lateral extent (as ignimbritic bodies). These are interpreted as cinerites, which resulted from ash falls from the eruptive column that were possibly transported several kilometers from the emission source by wind (see Martí, 1996).

(2) - Fluvial (or more generally alluvial) structures are recognized in several levels throughout the Lower Red Unit, displaying the same rock composition than that of the volcaniclastic strata. Volcaniclastic intervals are often characterized by muddy 
surfaces with flow and wave ripples, mud-cracks, raindrops, root traces (often greenish), scarce plant fragments, bioturbations (both vertical and horizontal), arthropod trace fossils, and a wide variety of tetrapod footprints (Mujal et al., 2016a) (Supplementary Data S2). Such features indicate that volcaniclastics underwent water reworking and weathering processes. Most commonly, these structures are only found at the uppermost surface or at a few layers of the topmost part of each volcaniclastic interval (Fig. 6C). This suggests that surfaces were exposed for a relatively short time and/or that water flow was relatively low. In these cases, raindrops, mud-cracks, surficial arthropod trackways and cylindrical (both vertical and horizontal) burrows are common. Mujal et al. (2016a) defined these intervals as unconfined runoff surfaces; similarly, Martí (1996) suggested that explosive eruptions prompted rainfalls that would generate water runoff flows.

Occasionally, thick (up to $11 \mathrm{~m}$ ) intervals composed of volcaniclastics had been completely reworked by water. In these cases, deposits composed of thin-laminated fine- to medium-grained sandstones display erosive bases, cross stratifications with internal climbing, wave and flow ripples (resulting from lateral accretion) (Fig. 6H). These deposits correspond to point bars of fluvial meandering systems (Mujal et al., 2016a). Interestingly, sandstone layers preserve fine laminations, indicative of low bioturbation (Simon et al., 2016). These well-developed fluvial deposits can be correlated across hundreds of meters (Fig. 1B); they are equivalent to the volcaniclastic sandstone facies of Martí (1996) (see Section 5 below). As pointed out by Mujal et al. (2016a), these deposits resulted from periods of perennial presence of water, in more humid conditions than those of unconfined runoff surfaces.

Thin sections of rock samples revealed the presence of small ooid-like structures within red mudstones (Fig. 6I). These ooid-like structures are rounded, millimetric 
particles with concentric laminae distinguished by different coloration; the cores of these particles are tiny lithic fragments. The reddish matrix is completely fractured and infilled by sparry calcite, denoting prolonged periods of expansion and retraction. Ooids form within a water table, but red mudstones formed subaerially or under well-drained conditions; therefore, the combination of structures indicate that a vadose zone existed, i.e., with recurrent or periodic water-logging.

\subsection{Paleopedology}

\subsubsection{Grey Unit pedotypes}

Coal seams are characteristic deposits of the Grey Unit (Fig. 3A). They commonly preserve distinctive plant remains. Coals are found at the top of meandering channel fill sandstone deposits, and they also appear interbedded within floodplain mudstones (Figs. 3A, C, 4A, B). These coal deposits represent the organic layers of weakly degraded plants interpreted as pedotype $\mathrm{O}$ and $\mathrm{A}$ horizons of Histosols (Mack et al., 1993; Tabor et al., 2008), although no clear root traces have been identified so far in the underlying sandstone or mudstone host rocks, which would represent $\mathrm{C}$ horizons (Fig. 4A, B). Together, mudstones and coals correspond to floodplain deposits where paleosols (Histosols) developed under humid conditions, as previously suggested by Gascón and Gisbert (1987) from other Grey Unit Pyrenean localities. Some sandstone intervals, mostly corresponding to overbank deposits and uppermost parts of meandering fluvial channels, display nodule-like cracked structures with ferric crusts (Fig. 4C). Gascón and Gisbert (1987) interpreted these structures as ferric and lateritic paleosols (occurring both at Grey and Transition units). Large ferric nodules parallel to stratification and embedded in floodplain carbonaceous mudstones also occur (Fig. 4D). 
Additionally, in the Grey Unit succession at the westwards Pyrenean Erillcastell site (see Besly and Collinson, 1991), large reddish nodules within sandstones and gley structures have been identified. They would be equivalent to the ferric Argillisols described by Tabor et al. (2008) in the late Carboniferous of western Pangea, thus we refer to these structures as ferric horizons.

\subsubsection{Transition Unit pedotypes}

The Transition Unit displays substantially different pedotypes than those of the Grey Unit, although some are equivalent, such as the sporadic Histosols occurring at the uppermost Transition Unit in Coll de Sas (Supplementary Data S1), as well as the ferric horizons described below.

The most abundant pedogenic features of the Transition Unit (in both studied localities) are large fractures, showing smoothed (polished) surfaces with slickensides, that obliquely cross the greenish/greyish mudstones (Fig. 5B). Such structures are interpreted as slickensides resulting from the expansion and retraction (swelling and shrinking) of clay minerals (Mack et al., 1993), most possibly corresponding to kaolinite, illite, illite/montmorillonite interstratifications and montmorillonite (Gisbert, 1981), and possibly chlorite (see Nagtegaal, 1969), although further deep investigations are necessary. In sum, slickensides in mudstones correspond to pedotype horizons BCss, being characteristic of Vertisols (Mack et al., 1993).

At 79 and $85 \mathrm{~m}$ of the measured Coll de Sas section, large (up to $70 \mathrm{~cm}$ of diameter) septarian nodules occur in the Transition Unit (Fig. 5C-E; Supplementary Data S1). Septaria are silicified, oxidized (reddish/brownish, ferruginized), large and rounded boulders displaying both radial and concentric cracks that evidence different episodes of fracture growing (Fig. 5D, E). The septaria levels are laterally traced along 
the entire Coll de Sas locality corresponding to the correlation level of the measured section with the two complementary sections where plant fossils were located (Supplementary Fig. S1). The oxidized coloration may denote a high ferric content, as has been previously identified in the Transition Unit (Gascón and Gisbert, 1987), thus representing ferric horizons. The septarian nodules are embedded in greenish mudstones and fine-grained sandstones with large slickensides as those previously described, building up pedotype horizons BCss and Bss (Fig. 5C). These vertic features, together with the greenish color, indicate waterlogging and low redox conditions, and are diagnostic of gleyed Vertisols (Mack et al., 1993). Septaria occur in two specific levels that are laterally traced along the entire Coll de Sas locality, being a marker for the correlation of the measured section with the two complementary sections where plant fossils were located (Fig. 1B; Supplementary Fig. S1).

From the middle part ( $76 \mathrm{~m}$ of the measured section) to the top of the Transition Unit at Coll de Sas, carbonate nodules occur within the mudstones, increasing in abundance and size from the base to the top of the Transition Unit (Supplementary Fig. S1, Data S1). Such nodules are rounded to oval-shaped, in the latter case with the long axis parallel to stratification; they are greyish to whitish. The largest carbonate nodules (> $5 \mathrm{~cm}$ in diameter) occur between 109 and $129 \mathrm{~m}$ of the measured section, where they are coalesced, forming plains parallel to the stratification (Fig. 5F, G; Supplementary Data S1). Mudstones with carbonate nodules also display slickensides, constituting pedotype horizons Bkss and BCkss (Fig. 5F'). When vertic features predominate, these pedotypes are classified as calcic Vertisols, but when carbonate nodules (occasionally) predominate (and define stratigraphic horizons) these pedotypes can be considered vertic Calcisols (Tabor et al., 2008) (Fig. 2; Supplementary Data S2). 


\subsubsection{Lower Red Unit pedotypes}

The most abundant pedotypes of the Lower Red Unit are those displaying calcic features, most commonly carbonate nodules and/or indurated carbonate horizons (i.e., Calcisols in the sense of Mack et al., 1993; calcretes in the sense of Alonso-Zarza and Wright, 2010). Besides calcic-related pedotypes, as explained below, the Lower Red Unit also displays many other paleosol horizons in specific or peculiar stratigraphic levels. Nagtegaal (1969), Gascón and Gisbert (1987), Aso et al. (1992), Martí (1996) and Gretter et al. (2015), among other works, already mentioned the presence of predominating carbonate horizons in the Pyrenean lower Permian red-beds successions, commonly composed of volcaniclastic deposits.

The lowermost reddish mudstones from the Lower Red Unit at Coll de Sas display carbonate nodules parallel to stratification and slickensides, being similar to those of the Transition Unit (see Section 4.2.2 above). They constitute horizons Bkss, and the type of carbonate nodules correspond to the Stage II of Gile et al. (1966) and Machette (1985), being features of vertic Calcisols (cf., Mack et al., 1993). Interestingly, as stated in Section 4.1.3 above, thin sections revealed structures in these reddish mudstones (Fig. 6I), suggesting water table fluctuations.

Regarding the Lower Red Unit pedogenic features from Les Esglésies, a wide variety of elements, structures, horizons (mostly horizons $\mathrm{B}$, but also occasional horizons $\mathrm{A}, \mathrm{AB}, \mathrm{BC}$ and $\mathrm{C}$ ), and profiles are identified (Figs. 7, 8A-G; Supplementary Data S2). As stated above, the most common elements are carbonate nodules developed in the volcanic red mudstones, siltstones and fine-grained sandstones, representing horizons B (Fig. 7). Carbonate nodules are often globular or equidimensional but, in some cases, they are parallel (horizontal) and/or perpendicular (vertical) with respect to 
stratification (Fig. 7A-C). Nodule sizes range from $<1 \mathrm{~cm}$ to $\sim 20 \mathrm{~cm}$, often being larger when they are more abundant, and constituting horizons Bk and Bkk (Stages II and IIIIV, respectively, of Gile et al., 1966; Machette, 1985). In the horizons where carbonate nodules are of largest size, they are assigned to Stage V of Machette (1985). Most of vertical nodules possibly correspond to carbonate concretions around root traces (rhizoliths) penetrating red mudstones (Fig. 7H); Tabor and Montañez (2004) identified similar pedotypes that were classified as Aridisols (equivalent to Calcisols). A peculiar interval with carbonate nodules is found from 688 to $694 \mathrm{~m}$ of the measured section (Supplementary Data S2), where small nodules $(2-3 \mathrm{~cm})$ are embedded within large nodules (up $10 \mathrm{~cm}$ ). The grey cinerites are commonly associated to well-developed horizons of carbonate nodules (horizons $\mathrm{Bk}$ and Bkk). Horizontally enlarged nodules correspond to coalesced nodules, building up indurated levels and corresponding to horizons Bkk and Bkkm (Stages III and IV of Gile et al., 1966, and Stages III-V of Machette, 1985) (Fig. 7D-F). In the sense of Alonso-Zarza (2003), such indurated calcic horizons correspond to platy or laminar horizons.

The lowermost part of the Lower Red Unit at Les Esglésies (42-67 m of the measured section) preserves several thick, indurated calcic horizons (up to $40 \mathrm{~cm}$ ) that in some cases are completely cemented and nodules are not distinguished. They are classified as horizons Bkkm (Stage IV of Gile et al., 1966; Stage V of Machette, 1985) (Fig. 7D-F), which correspond to Calcisols as defined by Mack et al. (1993). Commonly, these horizons display eroded upper surfaces and channel-like shapes in their lower surfaces (Fig. 7F). In some cases, successions of amalgamated indurated calcic horizons, bounded by sharp channel-form surfaces (convex to the lower surface), occur (Fig. 7F). This is indicative of intermittent soil development and reactivation of ephemeral water flows (Mack et al., 2003, and references therein; see also Gascón and 
Gisbert, 1987). Similarly, this lower interval of the Lower Red Unit also preserves redpurplish mudstones with discolored greenish zones (i.e., gleyed) and isolated nodules that end with thick horizons of coalesced nodules displaying slickensides in the lower surfaces (Fig. 7D, E). These pedotype horizons build up paleosol profile of Bkw/BkssBkkm, which are characteristic of vertic Calcisols. Additionally, these pedotypes often contain carbonate nodules with radial and concentric cracks infilled of sparry calcite (septarian nodules; see also Aso et al., 1992) (Fig. 7G, G'). In the same way, the indurated calcic horizons are also commonly cracked (planar septaria of Gascón and Gisbert, 1987 and Aso et al., 1992). These fractures indicate expansion and retraction of the soil (Mack et al., 1993; Tabor and Myers, 2015). Other common Lower Red Unit pedotypes display no pedogenic features other than carbonate nodules composed of horizons Bk and profiles Bk-Bkk (Stages II and III of Gile et al., 1966 and Machette, 1985) (Fig. 7A). These Calcisols are similar to the Aridisols of Tabor and Montañez (2004). Occasional breccia levels composed by angular limestone clasts indicate calcrete reworking by pyroclastic flows (e.g., at $81.4 \mathrm{~m}$ of the measured section).

Throughout the rest of the succession, horizons with carbonate nodules are combined with other pedogenic elements, constituting different horizons and paleosol profiles (Fig. 8A-F; Supplementary Data S2). Most commonly, these calcic pedotypes are characterized by mud-cracked surfaces and/or slickensides (horizons Bkw and Bkss) and discolored greenish (gleyed) zones (horizons Bkg), but others are only characterized by carbonate nodules (horizons $\mathrm{ABk}, \mathrm{Bk}$ and $\mathrm{Bkk}$, occasionally $\mathrm{Bkkm}$ ); similarly, nodules are usually decolored (whitish) with respect to the mudstone matrix (reddish). These features are typical of vertic Calcisols; however, in some horizons, vertic features prevail over calcic features (e.g., those with meter-scale slickensides and $\sim 1-2 \mathrm{~cm}$ nodules, with mudstones displaying wedge-shaped peds), thus in these cases paleosols 
are calcic Vertisols (Fig. 8D-F). Occasionally, intervals of thinly laminated claystones contain sporadic (and isolated) carbonate nodules. Tentatively, these intervals could correspond to calcic Argillisols (cf., Tabor et al., 2008). According to Gisbert (1981), in eastern areas of the Catalan Pyrenees, the Lower Red Unit clay minerals composing the reddish mudstones are illite, illite/montmorillonite interstratifications, chlorite, kaolinite and montmorillonite.

Pedogenic horizons without carbonate nodules are less common but present. Among them, horizons with greenish root traces, gleyed zones and mud-cracked surfaces are interpreted as horizons $\mathrm{ABw}$ of gleyed Vertisols (Fig. 8A-C, E). Relatively thin siltstone/fine-grained sandstone layers with root traces (often green) and occasional cylindrical burrows would correspond to immature paleosols (horizons A and C of Protosols) (Fig. 8G). Horizons $\mathrm{ABw}$ are also commonly found associated at strata boundaries with the overlying horizon composed of laminated claystones or greyish cinerites. Similarly, the presence of primary sedimentary structures (such as ripples) in horizons $\mathrm{AB}$ indicate incipient or immature soil formation. All types of Vertisols and some immature vertic Calcisols (i.e., horizons with $\sim 1-2 \mathrm{~cm}$ nodules and small mudcracks) are associated with the most water-reworked volcaniclastic intervals (i.e., the relatively well-developed meandering fluvial deposits). By contrast, Calcisols and welldeveloped vertic Calcisols are most commonly associated with volcaniclastic intervals nearly unaltered or reworked by water.

Besides the vertical variation of Lower Red Unit paleosols (though dominated by calcic pedotypes) throughout the measured section, we also observed slight differences in paleosol occurrences in laterally equivalent areas (of the same stratigraphic level). The paleosols below ignimbrite 3 projecting out of the relief (Figs. 6B) show slight lateral variations: whereas in the area where the section was measured 
(Fig. 8B) pedotype features are those of gleyed Vertisols, at $\sim 2.5 \mathrm{~km}$ eastwards (below the tetrapod footprint level MA-A1a of Mujal et al., 2016a) (Fig. 8A) the pedotype features are those of gleyed calcic Vertisols. Such lateral variations have already been recognized elsewhere (Krauss, 1999; Alonso-Zarza, 2003; Rosenau et al., 2013). Rosenau et al. (2013) documented similar examples as that of the Lower Red Unit exposed above, and attributed such lateral pedotype variations to differences in soil drainage according to the location within the basin. As stated by these authors, these lateral pedotype variations are the result of the combination of autogenic (local) and allogenic (i.e., glacioeustasy and climate) controls. Therefore, as discussed in Section 5.2 below, we suggest that a global, climatic imprint characterizes the studied succession.

\subsection{Paleontological content}

\subsubsection{Grey Unit fossils}

Plant remains are found in numerous levels through a nearly $45 \mathrm{~m}$ thick section at the Grey Unit of Coll de Sas (Fig. 2; Supplementary Fig. S1). Most of plant-bearing beds consist of dark mudstones and fine sandstones sometimes associated to channel deposits (Supplementary Text S1, Fig. S1). However, plant debris may also occur in medium to coarse sandstones. Isolated leafy whorls and fragments of branches or stems of horsetails (Calamitales and Sphenophyllales) and detached pinnae to partial fronds of tree ferns (Marattiales and, less frequently, Zygopteridales), as well as seed ferns (Medullosales), are abundant in most of the studied plant-bearing beds (Figs. 9-11). Fragmentary ribbon shaped leaves with parallelodromous venation assigned to Cordaitales are common, but elements associated to remains of Pteridophytes and seed 
ferns are less abundant. Reproductive structures, such as isolated cones (Figs. 9F, G, $10 \mathrm{H}$ ), are very scarce. Occasionally, large logs may occur in coarse sediments (Fig. 11E). Accumulations of plant remains range from massive (Fig. 11B) to sparse (Fig. 11D).

Within Equisetopsids, Annularia sphenophylloides and A. stellata as well as remains of Sphenophyllum are recurrent throughout the series (Fig. 9A-E; Supplementary Fig. S1). A well-preserved cone of Calamostachys was found associated with foliage of Annularia in a horizon located $28 \mathrm{~m}$ above the base of the Coll de Sas NW section (Fig. 9F; Supplementary Fig. S1). According to Doubinger et al. (1995), Calamostachys cones and Annularia foliage belong to horsetails of the genus Calamites. As a whole, fern foliage is more diverse and includes Marattiales and Zygopteridales. Within the former, Pecopteris, Diplazites, Polymorphopteris and Lobatopteris are identified. Fronds and isolated pinnae of Pecopteris are conspicuous along the series and include $P$. robustissima and foliage reminiscent of $P$. arborescens and P. jongmansii (Fig. 9). Among the remaining species of Marattiales, Diplazites emarginatus and Polymorphopteris polymorpha are distinguished (Fig. 9). On the other hand, Zygopteridales are represented by a single species, Nemejcopteris feminaeformis (Fig. 9H), only found in two levels within the coal interval at $28-29 \mathrm{~m}$ of the measured section (Supplementary Text S1, Fig. S1).

Seed ferns are also diverse and widely distributed throughout the Coll de Sas section (Supplementary Fig. S1). They belong to Medullosales and comprise the genera Odontopteris, Callipteridium, Alethopteris and Neuropteris (Fig. 10). Within Odontopteris, most specimens are assigned to O. brardii (Fig. 10A, B), which is very common in the area, whereas some others belong to another uncertain form-species similar to O. cantabrica (Fig. 10C). Foliage of Callipteridium is also abundant and 
includes the species C. zeilleri (Fig. 10D). Among ribbon-shaped leaves assigned to Cordaitales, Cordaites and Poacordaites are recognized (Fig. 10F, G). Finally, evidence for Lepidodendrales is only supported by a fragment of Sigillariostrobus cone recovered from the Coll de Sas W section (Fig. 10H).

The lack of evidence for roots and the variable degree of fragmentation of leaves and stems suggest parautochthony or allochthony for most of the studied plant-bearing levels (Fig. 11). However, in many cases, sphenopsid foliage as well as isolated pinnae and partial fronds show neither signs of abrasion nor angulose breaks, and preserve delicate venation in their fragile laminae. In addition, there is no selection for organs, size and shape, and plant remains are usually randomly orientated (Fig. 11D, E). This would be consistent with low water transport and low agitation from neighboring source areas before deposition on the floodplain (Martín-Closas and Gomez, 2004). Based on taphonomic analyses carried out in the neighboring eastwards localities of Surroca and Ogassa (Castellar de n’Hug sub-basin), Martín-Closas and Martínez-Roig (2007) suggested that in the Stephanian (late Carboniferous) Pyrenees, marattialean tree ferns and medullosan pteridosperms grew close to the floodplains, which were settings generally devoid of vegetation. In the same basin, sphenopsids mainly grew in fluvial channels, whereas peat mires and distal areas of alluvial fans were inhabited by lycopsids and cordaitaleans, respectively. Preliminary data from Coll de Sas could agree with a distribution of vegetation similar to that of the Castellar de n'Hug sub-basin, but further and detailed bed-by-bed taphonomic analyses (out of the scope of this work) are needed to confirm or reject this hypothesis. For instance, there is evidence for differential habitat preferences for marattialean tree ferns with pecopterid foliage in similar environments within intermountain basins from Ogassa-Surroca (southern 
Pyrenees) and Graissessac-Lodève (southern France) (Martín-Closas and Galtier, 2005; Martín-Closas and Martínez-Roig, 2007).

\subsubsection{Lower Red Unit fossils}

The Lower Red Unit red-bed succession at Les Esglésies is mainly built up of deposits affected by pedogenesis denoting relatively dry conditions (Gascón and Gisbert, 1987). Nevertheless, occasional intervals with evidence of perennial water appear along the succession (Fig. 2). In these relatively humid intervals, tetrapod footprints have been identified. Mujal et al. (2016a) described three intervals bearing different ichnoassociations. Voigt and Haubold (2015) also reported footprints from the same area but from different intervals. The Lower Red Unit preserves at least eight different ichnotaxa (Batrachichnus, Limnopus, cf. Amphisauropus, cf. Ichniotherium, Varanopus, cf. Varanopus, Hyloidichnus, Dromopus and Dimetropus) as well as three types of swimming traces (Characichnos) associated to Batrachichnus, Limnopus and cf. Amphisauropus (Characichnos types A, B and C of Mujal et al., 2016a).

The most extended ichnoassociation of Mujal et al. (2016a) is recognized at three sites from the same stratigraphic level covering $\sim 1.5 \mathrm{~km}$ distance; it is associated with well-developed meandering systems and composed of up to six ichnotaxa, being dominated by temnospondyl footprints (Batrachichnus and Limnopus) and associated Characichnos (i.e., water-dependent trackmakers and/or impressed under water table). The less extended ichnoassociation of Mujal et al. (2016a) is recognized at two different levels; it is associated with unconfined runoff surfaces (with desiccation evidence such as rain drop imprints and mud-cracks) and reveals low diversity (only Hyloidichnus and Dimetropus), suggesting the absence of water-dependent trackmakers. Similarly, the invertebrate trace fossil distribution is also linked to water availability (Mujal et al., 
2016a). In sum, all these features suggest different environmental conditions throughout the succession, which is in accordance with the different pedotypes identified. The new ichnite-bearing level here reported (at $\sim 358 \mathrm{~m}$ of the measured section, see Supplementary Data S2) also supports these observations: footprints are preserved at the base of point bars of meandering fluvial systems, and correspond to Batrachichnus (temnospondyl branchiosaurid and lepospondyl trackmakers) and Characichnos.

Besides rhizoliths of calcic paleosols, plants are evidenced by scarce fragments. They are mostly unidentifiable and always associated with tetrapod ichnite intervals. Only two plant specimens, from different sites, preserve characteristic features: they are composed of three rows of alternated oval-shaped impressions (Fig. 8H, I), resembling walchian fronds such as Pagiophyllum-type conifer twigs (Galtier and Broutin, 2008, their Fig. 6A). Similarly, Broutin and Gisbert (1985) reported Walchia sp. in nearby Lower Red Unit localities.

\subsection{Paleomagnetism: magnetic polarity stratigraphy}

A total of 40 specimens were stepwise demagnetized from the Coll de Sas sampling sites following the combined protocol previously outlined (selected samples in Supplementary Fig. S2A-F). The NRM intensity for the Coll de Sas samples is generally in the range $0.1-1 \times 10^{-3} \mathrm{~A} / \mathrm{m}$, with most being around $0.2 \mathrm{~mA} / \mathrm{m}$. Stepwise demagnetization of the samples often shows an unstable behavior upon demagnetization (Supplementary Fig. S2F) and no characteristic remanent magnetization (ChRM) component can be defined. We classify this type of bad quality samples as Class 3 . They account for $40 \%$ of the analyzed samples. A few samples (15\%) display stable linear demagnetization trajectories (Supplementary Fig. S2E). A low temperature- 
coercivity viscous component is first demagnetized up to $25 \mathrm{mT}$. A ChRM component trending towards the origin of the demagnetization diagram is then removed up to 100 mT. The type of high-quality samples is ranked as Class 1 . The rest of the samples (45\%) display noisy trajectories often not trending towards the origin after removing the viscous component, and they constitute the Class 2 group of samples. A tentative magnetic component has been calculated for those samples but not used for magnetostratigraphy (see discussion below).

For Les Esglésies section a total of 26 red-bed specimens have been fully demagnetized. NRM intensity is high in the range of $2-27 \times 10^{-3} \mathrm{~A} / \mathrm{m}$, usually around 15 $\mathrm{x} 10^{-3} \mathrm{~A} / \mathrm{m}$. Combined thermal and alternating field (AF) demagnetization (Supplementary Fig. S2A-D) produces high-quality Class 1 samples in all instances. In addition to the removal of a secondary viscous overprint below 17-20 mT (L component), which can be very small or absent in some samples, a well-defined ChRM component is removed. AF demagnetization up to $100 \mathrm{mT}$ hardly removes any magnetization in some samples (Supplementary Fig. S2C, S2D), indicating that the ChRM is entirely blocked in a high-coercivity component that starts to unblock at relatively low temperatures $\left(400-450^{\circ} \mathrm{C}\right)$ and persists up to $690^{\circ} \mathrm{C}$, suggesting hematite as the magnetic carrier. In other samples, the ChRM components starts to unblock upon the AF demagnetization above $20 \mathrm{mT}$ but does not unblock totally until thermal demagnetization at high temperature (Supplementary Fig. S2C, S2D). In these cases, a mixed magnetic mineral assemblage is likely. The combined demagnetization strategy suggests the presence of a low-coercivity magnetite-like mineral phase together with the high-coercivity hematite phase. Further evidence for the mixed mineral magnetic carriers composition comes from some additional rock-magnetic experiments. Hysteresis loops and coercivity remanence curves are, in some cases, indicative of the 
composite magnetic assemblage (Supplementary Fig. S2G). These hysteresis loops are "wasp-waisted" in shape (Roberts et al., 1995) while isothermal acquisition curves do not saturate at the maximum field applied (1T). Moreover, a break in slope at low applied back-field values, indicated by an arrow in Supplementary Fig. S2G-2, is an indication of the presence of a low remanent coercivity fraction (probably magnetite) in addition to the high-coercivity hematite phase.

Computed L component and ChRM directions for les Esglésies samples, both before and after bedding tilt correction, are shown in Supplementary Fig. S3. A stability fold test is not possible for the present dataset as the studied section displays a homogeneous bedding attitude. However, the general tilt of about $40^{\circ}$ towards the S-SW permits comparison of the computed mean directions before and after tilt correction. The L component is clearly a recent secondary overprint that conforms to the geocentric axial dipole field (GAD) in in situ coordinates (Supplementary Fig. S3A). Conversely, when tilt correction is applied, the mean ChRM component shows a southerly and shallowing upward direction (Supplementary Fig. S3A) (Dec/Inc $=182.2 /-4.3 \alpha_{95}=6.1$ ). This is compatible with published Permian data and paleopoles (i.e., Parés, 1988; Van der Voo, 1993), while it has non-geological significance in in situ coordinates. Consequently, we take the ChRM as a pre-tilt component, most likely of primary origin, which is used to determine magnetic polarity. The intermediate mean magnetic inclination of about $42^{\circ}$ in tilt-corrected coordinates, together with the shallow inclination in in situ coordinates (before tilt correction), suggests a secondary origin for the magnetization (see discussion below). Therefore, these results hamper any attempt to retrieve a magnetostratigraphy for this section.

\section{Discussion}




\subsection{Age constraints}

Plant species identified in the Grey Unit at Coll de Sas section are most likely consistent with a Stephanian C age. According to Wagner and Álvarez-Vázquez (2010), the abundance of Odontopteris brardii (frequent in the upper Stephanian but rare in the lower Stephanian), and the occurrence of Pecopteris jongmansii, P. robustissima and Callipteridium zeilleri (missing in the middle-upper Autunian from the Iberian Peninsula), suggest this age. Additionally, the stratigraphically-lateral equivalent beds at Erillcastell (4.21 km westwards) also correspond to Stephanian C (Talens and Wagner, 1995). These two localities share floral elements such as Annularia stellata, Sphenophyllum oblongifolium, Odontopteris brardii, Callipteridium zeilleri, Polymorphopteris polymorpha and P. robustissima. More extensively, the studied plant fossil assemblages could be coeval with Stephanian floras from Ogassa and Surroca (Eastern Catalan Pyrenees; Martín-Closas and Roig, 2007), the Cantabrian Mountains (NW Iberia; Wagner and Álvarez-Vázquez, 2010), Graissessac-Lodève (southern France; Martín-Closas and Galtier, 2005) and Montceau-les-Mines (Central Massif, France; Charbonnier, 2014). Other similar plant assemblages supporting a Stephanian C age for Coll de Sas floras are those from the Saar-Nahe basin of Germany (Kerp and Fichter, 1985; Uhl and Jasper, 2016), the Czech Republic basins (Opluštil et al., 2013, 2017a, 2017b), as well as from the further western Pangean equatorial basins (e.g., New Mexico, USA; DiMichele and Chaney, 2005; DiMichele et al., 2017).

Regarding the Transition Unit, no biostratigraphic data are available, but in the Lower Red Unit, Voigt and Haubold (2015) and Mujal et al. (2016a) suggested an Artinskian age based on similar ichnoassemblages from: (1) the neighboring Peña Sagra 
Fm of the Spanish Cantabrian mountains (Gand et al., 1997), the Moroccan Tiddas Basin (Voigt et al., 2011), the Viala and Rabejac Fms of the French Lodève Basin (Gand and Durand, 2006) and the Italian Southern Alps (Avanzini et al., 2011); and (2) the western Pangean tracksites at the Hermit Fm (Arizona, USA; Lucas, 2007) and the Abo and Robledo Mountains Fm (New Mexico, USA; Voigt et al., 2013).

Recent studies on Permian tetrapod ichnostratigraphy (Marchetti, 2016; Voigt and Lucas, 2016) found that: (1) Hyloidichnus, a well-represented ichnogenus of the Lower Red Unit, is only found in Artinskian and younger strata; (2) Erpetopus, an index ichnotaxon for the Kungurian, has not been so far reported for the Lower Red Unit; (3) Ichniotherium, possibly found in the Lower Red Unit (cf. Ichniotherium of Mujal et al., 2016a), is not found in strata younger than Artinskian. Therefore, an Artinskian age for Lower Red Unit ichnites is appropriate.

Regarding paleomagnetic data, the limited number of Class 1 samples for the Coll de Sas section (Fig. 12) hampers a well resolved magnetostratigraphy. Despite more than one specimen being demagnetized for most sampling sites, there are only two small stratigraphic portions that can be assigned polarity (reverse intervals at $75 \mathrm{~m}$ and $122 \mathrm{~m})$ (Fig. 12). A single normal sample in the lower part (18 $\mathrm{m}$ ) has to be regarded as insufficient and it is drawn as a half-width polarity band (Fig. 12). Consequently, it is challenging to make any attempt at magnetostratigraphic correlation. On the other hand, the high quality of the Les Esglésies sample collection allows inferring reverse polarity throughout the section (Fig. 12). Given the long expanded interval of reverse polarity and the biostratigraphic constraints and absolute ages (see below), we directly correlate it to the Kiaman reverse Superchron (Hounslow and Balabanov, 2016). In the most recent Permian polarity timescale, the Kiaman Superchron extends up to the mid Guadalupian Epoch (or early Wordian stage) at about $266 \mathrm{Ma}$ (Hounslow and 
Balabanov, 2016) where the mixed Illawarra Superchron begins. This implies that the studied LRU section is no younger than earliest middle Permian. In addition, Mujal et al. (2016b) reported a caseid vertebra from the Upper Red Unit tentatively correlated to the early Wordian. The Upper Red Unit, preserved in eastwards Catalan Pyrenean localities (Mujal et al., in press), overlies the Lower Red Unit by means of an angular unconformity (Gisbert, 1981; Speksnijder, 1985; Gretter et al., 2015).

The Lower Red Unit bio-magnetostratigraphy is supported by absolute dating of

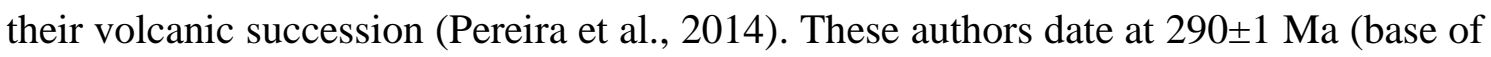
the Artinskian) (Fig. 13) the so-called Castellar de n'Hug ignimbrite (ignimbrite 4 in our Figs. 1, 2, 6B), which has a regional extent and can be correlated from the dated point until the section here studied (Martí, 1996; J. Martí pers. comm. 2017). Furthermore, the lower tetrapod ichnoassociation of Les Esglésies (Mujal et al., 2016a) would correlate with the Viala Fm from the Lodève Basin, which preserves a tuff bed of ca. 290 Ma (Michel et al., 2015). Both French and Catalan ichnoassemblages display the same ichnotaxa (Gand, 1988; Gand and Durand, 2006; Mujal et al., 2016a). More tentatively, Hyloidichnus is only found in the upper ichnoassociation of Les Esglésies (Mujal et al., 2016a), and the lower appearance of this ichnotaxon in the Lodève Basin is at the Rabejac Fm (Gand and Durand, 2006), aged early-middle Artinskian (Michel et al., 2015).

Finally, in relation to the Pyrenean magmatic and eruptive overlapping intervals of Pereira et al. (2014), the Grey Unit was deposited during the first phase (ca. 309-307 Ma; late Carboniferous), the Transition Unit during the second phase (ca. 304-296 Ma; late Carboniferous-early Permian), and the entire Lower Red Unit during the third (ca. 294-282 Ma) and fourth (ca. $276 \mathrm{Ma}$ ) phases (early Permian). 


\subsection{Paleoclimatic trend and global correlation}

The three studied units display distinct sedimentological features and pedotypes that draw a general aridification trend, from humid to semi-arid and arid conditions across the Carboniferous-Permian $(\mathrm{C}-\mathrm{P})$ transition, with occasional relatively humid shifts (Fig. 13). The most evident features are: (1) the drop of coal content from the Grey Unit to the Transition Unit, and (2) the sudden shift from the Transition Unit grey/greenish-beds to the Lower Red Unit red-beds, with also a coal disappearance. These changes are linked to a pedotype succession that is dominated by Histosols in the Grey Unit, Vertisols in the Transition Unit and Calcisols in the Lower Red Unit (Fig. 2; Supplementary Data S1, S2). This succession has a good potential for paleoclimatic determinations by paleosol geochemistry (Sheldon and Tabor, 2009), although tectonic imprint could be a negative factor (see Nagtegaal, 1969), as found in the French Lodève Basin (Michel et al., 2015, 2016). Our paleoclimatic inferences are therefore based on the field study of paleosols.

According to Cecil (2003), in modern soils, coal is formed in environments with precipitation exceeding $1000 \mathrm{~mm} /$ year, and precipitation higher than evapotranspiration for at least 10 months per year. Therefore, Grey Unit Histosols indicate humid conditions during late Carboniferous times. In accordance, during the late Stephanian, Pyrenean floras grew up in intermountain basins where environments evolved from perennially wet conditions, with a mixture of hygrophile and mesophile floral elements, to drier conditions with a greater proportion of mesophile and xerophile taxa (Wagner and Álvarez-Vázquez, 2010). The abundance of tree ferns and sphenopsids throughout the Coll de Sas series suggests more humid habitats prior to the Permian drier climate. Otherwise, Zygopteridales ferns evidence adaptations to water-deficient habitats 
(Phillips and Galtier, 2005), thus suggesting seasonally dry conditions, as have already been documented in the late Carboniferous (DiMichele et al., 2010; Falcon-Lang et al., 2011; DiMichele, 2014; Opluštil et al., 2017a). DiMichele (2014) pointed out that a preservation/taphonomic bias exists between "wet" and "dry" floras because wet environments, both in space and time, dominated over dry environments. This would explain why floras adapted to water-stressed conditions are sparse throughout the Coll de Sas succession, being only found in the thickest coal interval where preservation potential is enhanced. Gascón and Gisbert (1987) also identified gleyed horizons throughout other Pyrenean Grey Unit successions, denoting seasonal (possibly monsoonal) precipitation. Similarly, ferric and oxidized horizons throughout the Grey Unit suggest well-drained conditions (cf., Tabor et al., 2008) and abundant precipitation (Gascón and Gisbert, 1987).

The dominant Transition Unit pedotypes are Vertisols, which are developed in climates under strong seasonal precipitation (such as in Mediterranean or monsoonal climates) or in episodic fluctuations of the water table (Mack et al., 1993; Tabor and Montañez, 2004; Tabor et al., 2008; Michel et al., 2015, and references therein). The most common and evident features are large-scale slickensides, indicative of shrinkswell processes resulting from the alternation of wet and dry cycles (Mack et al., 1993). Specifically, two main intervals are observed throughout the Transition Unit (Fig. 2; Supplementary Data S1): (1) the lower part is dominated by Vertisols and occasional gleyed Vertisols (humid conditions) (Tabor et al., 2008); (2) the upper part of the unit is dominated by calcic Vertisols and occasionally by vertic Calcisols (sub-humid to semiarid conditions) (Tabor et al., 2008). Notably, the thin coal layers above the lacustrine deposits (Fig. 2; Supplementary Data S1, S2) would denote sporadic water-logging and reduced sedimentation rates, possibly linked to the final phases of lake infilling. 
Seasonally-varying precipitation is the most likely scenario for the formation of vertic profiles (Gascón and Gisbert, 1987), but future petrographic studies may discern soil-forming processes (Michel et al., 2015). Moreover, the pedotype stacking of the entire $\sim 1000 \mathrm{~m}$ thick succession is equivalent to that of the French Graissessac-Lodève Basin (Michel et al., 2015). Under this premise, the Transition Unit pedotype succession indicates a progressive trend towards well-drained environments and increased aridity. The age interval of the Transition Unit is deduced as latest Carboniferous-earliest Permian (see Section 5.1 above). This agrees with a monsoonal imprint on the unit, as such climate circulation was reached during the early Permian in the Northern Hemisphere (Tabor and Montañez, 2002).

The Lower Red Unit is dominated by calcic pedotypes (mostly Calcisols and vertic Calcisols, but also calcic Vertisols), thus most of pedogenic horizons display carbonate nodules (Fig. 2; Supplementary Data S2). Carbonate horizons are often linked to arid climates, but they are also developed in regions with high precipitation (AlonsoZarza, 2003; Tabor and Myers, 2015). This is also the case of indurated calcic or platy horizons: in modern soils, they generally form in sub-humid to semi-arid climates where evapotranspiration exceeds precipitation in most months of the year (Alonso-Zarza, 2003). Tabor and Poulsen (2008) found that calcretes are important lithologies in lower Permian rocks of equatorial Pangea, which indicate a trend to a more arid climate. The reddish (oxidized) color of the Lower Red Unit denotes well-drained conditions (Nagtegaal, 1969; cf., Mack et al., 2003). Therefore, these features, together with the formation of horizons Bk associated to root calcification (rhizoliths), green mottles, gleyed horizons, slickensides, and the early diagenetic small septarian nodules, together with the indurated calcic horizons, suggest strong seasonal precipitation in semi-arid to arid climates (Mack et al., 1993, 2003; Tabor and Montañez, 2004; Tabor et al., 2008; 
Tabor and Myers, 2015). A semi-arid to arid climate was suggested by Gascón and Gisbert (1987), who pointed to a mean annual precipitation of $<500 \mathrm{~mm} /$ year but $>100$ mm/year for the Lower Red Unit; similarly, Nagtegaal (1969) suggested that the predominance of calcic pedotypes throughout the Lower Red Unit is related with the aggradational stacking nature of such deposits.

Generally, indurated calcic horizons are developed over timescales of several hundred thousand years, indicating landscape stability (Mack et al., 2003, and references therein), although the time formation of such pedotypes depends of several factors (in some occasions favoring a rapid development), such as environmental setting, and degradational and aggradational regimes (Krauss, 1999; Alonso-Zarza, 2003). In the case of the Lower Red Unit, the relatively flat and stable landscape suggested by Nagtegaal (1969) would preliminary support long time periods of indurated calcic horizon formation. The early Permian flat landscape contrasts with the uneven relief during the late Carboniferous (Besly and Collinson, 1991). This may imply a decrease of tectonic activity, although such hypothesis should be explored in further studies. Similarly, Martí and Mitjavila (1988) and Martí (1996) suggested that the surge or emission area of volcanic material was located far from the ErillcastellEstac sub-basin, possibly also favoring a flat and stable landscape. In fact, some ignimbrites are tracked at a Pyrenean scale (Gisbert, 1986; Martí, 1996).

The lack of Histosols in the Lower Red Unit also indicates that early Permian climatic conditions were dryer than during the late Carboniferous, precluding peat formation (Michel et al., 2015). It is unlikely that sedimentation rates increased substantially, impeding organic matter accumulation. Accordingly, throughout the Lower Red Unit, different paleosol stacking patterns (independent of pedotypes) are observed. From one side, some profiles and horizons are transitional (both at base and 
top) from unaltered beds; and from the other side, they may show sharp (sometimes erosive) contacts. These differences are probably linked to changes in sedimentation/pedogenesis balance rates (Krauss, 1999). Therefore, as such changes affect all pedotypes, it can be concluded that pedogenic processes are linked to global climatic proxies, in this case, Permo-Carboniferous aridification. This link to global climatic proxies of paleosol development is also supported by the fact that the lateral variation of paleosols is not significative. As stated in Section 4.2.3 above, Rosenau et al. (2013) documented similar lateral variations attributed to autogenic controls, but with an allogenic (i.e., climatic) imprint. Such hypothesis also deserve further studies, comparing equivalent stratigraphic sections along the same basins and deepening in the paleosol analyses.

Throughout the Lower Red Unit there are occasional Vertisols (often with gley features) and other horizons lacking calcic features. These pedotypes are associated with the water-reworked volcaniclastic intervals (volcaniclastic sandstone facies of Martí, 1996). This correlation indicates increased precipitation and water availability, prompting the presence of fauna related to wet environments (represented by tetrapod footprints and invertebrate trace fossils) (Mujal et al., 2016a). Such deposits correspond to short humid periods interrupting the aridification trend. Notably, below both the Castellar de n'Hug ignimbrite of Martí (1996) and its equivalent ignimbrite 4 of this present study (see Section 5.1 above), water-reworked deposits are found (volcaniclastic sandstone facies of Martí, 1996, their Fig. 5) (at 170-181 m of Les Esglésies section, the meandering fluvial ichnoassociation of Mujal et al., 2016a). Hypothetically, these water-reworked deposits probably reflect global (climatic) rather than local events, as they are traced at Pyrenean scale. These short humid periods would correlate with the European-scale wet phases suggested by Roscher and Schneider (2006), who linked the 
short humid periods to sea-level fluctuations of an orbitally unknown cyclic recurrence of 5-7 Myr found throughout the Carboniferous and Permian periods. Similarly, Opluštil et al. (2017a) also documented grey lacustrine horizons interrupting the red beds succession of the Boskovice Basin from the Czech Republic.

Another potential correlation of the Pyrenean C-P terrestrial succession with global events is in the Southern Gondwanan glaciations (Isbell et al., 2012). The recurrent warming-cooling fluctuations, causing expansion and retraction of the Southern Gondwanan ice caps, are related with atmospheric $p \mathrm{CO}_{2}$ variation that eventually would drive sea-level fluctuations (Montañez et al., 2007, 2016; Isbell et al., 2012). In interglacial periods, the equatorial region suffered aridification and the subsequent formation of soils from semi-arid and arid climates. In glacial periods, the equatorial region experienced relatively more humid conditions than in interglacial periods, resulting in pedotypes characterized by organic matter accumulation (coal seams), as well as vertic and gley structures (and the development of fluvial systems suitable for life). In any case, all these pedotypes identified throughout the Lower Red Unit indicate strong seasonality. During the Permian, aridification increased, according to the prolongation of interglacial periods, but when glacial intervals took place, relatively humid conditions prevailed. Strikingly, Montañez et al. (2007) documented a drop of atmospheric $\mathrm{pCO}_{2}$ at the base of the Artinskian (at ca. $290 \mathrm{Ma}$ in the most recent chronostratigraphic chart by Cohen et al., 2013) coinciding with an Eastern Australian glaciation (Isbell et al., 2012) and with the Lower Red Unit lower meandering fluvial interval with abundant tetrapod footprints (Figs. 2, 13). At this point, the relatively humid intervals found along the different $\mathrm{C}-\mathrm{P}$ terrestrial successions may respond to atmospheric fluctuations linked to glaciations. 


\section{Conclusions}

The multidisciplinary study of the thick and continuous Carboniferous-Permian (C-P) terrestrial succession exposed in the western Catalan Pyrenees (NE Iberian Peninsula) allows us to document a series of events correlated to global changes (Fig. 13). The coupled bio- and magneto-stratigraphic data, together with previous works, give a relatively accurate age for the studied units that, together with the stratigraphic, sedimentological and paleopedological analyses permit to constrain the global aridification trend across the $\mathrm{C}-\mathrm{P}$ terrestrial successions of Central equatorial Pangea.

Macroflora from the Grey Unit, together with data from other localities correlated to the herein studied ones, suggest a Stephanian C age (late Carboniferous). During that times, a generally humid climate dominated, although short periods of drier conditions also occurred. The transition to the Permian shows an increase in seasonality and a progressive trend to semi-arid and arid conditions. Even though from the late Carboniferous to the early Permian the Pyrenean landscape changed substantially (cf., Nagtegaal, 1969), the local or regional tectonics and volcanic activity did not completely overprint global effects. The relatively humid intervals within the early Permian red-beds, preserving a relatively abundant tetrapod (ichno-) fauna, suggest short periods of interrupted aridity. Generally, the aridity trend of the Pyrenean Basin agrees with that of the nearby French Lodève Basin documented by Michel et al. (2015), supporting the pan-tropical aridification suggested by these authors. In addition, awaiting further analyses, the recurrent climatic shifts possibly reflect the glacialinterglacial fluctuations of the late Paleozoic ice age driven by fluctuations of the atmospheric $p \mathrm{CO}_{2}$. 


\section{Acknowledgments}

We acknowledge fieldwork support by Ruben Garcia-Artigas, José Ángel López, Mireia Plà and Pablo Rodríguez-Salgado. E. Mujal obtained financial support from the PIF grant of the Geology Department at $\mathrm{UAB}$, and from the Erasmus+ program of the UAB performed at the Paleontology Department from the Institut des Sciencies de l'Evolution (Université de Montpellier, France). E. Mujal received funding from the SYNTHESYS Project http://www.synthesys.info/ (FR-TAF-3621, FR-TAF-4808) which is financed by European Community Research Infrastructure Action under the FP7 "Capacities" Program. J. Fortuny acknowledges the support of the postdoc grant "Beatriu de Pinós" 2014 - BP-A 00048 from the Generalitat de Catalunya. This work received support from CERCA program (Institut Català de Paleontologia M. Crusafont, ICP) and from the projects "Vertebrats del Permià i el Triàsic de Catalunya i el seu context geològic" and "Evolució dels ecosistemes amb faunes de vertebrats del Permià i el Triàsic de Catalunya" (ref. 2014/100606), based at the ICP and financially supported by the Departament de Cultura (Generalitat de Catalunya). We deeply acknowledge the revision and handling by the editor Prof. Jasper Knight, as well as the comments and suggestions by Prof. Ana M. Alonso Zarza and two anonymous reviewers, which significantly improved a previous version of the manuscript.

\section{References}

Alonso-Zarza, A.M., 2003. Palaeoenvironmental significance of palustrine carbonates and calcretes in the geological record. Earth-Science Reviews 60, 261-298.

Alonso-Zarza, A.M., Wright, V.P., 2010. Calcretes. In: Alonso-Zarza, A.M., Tanner, L.H. (Eds.), Continental Carbonates. Developments in Sedimentology 61, pp. 225268. 
Aso, E., Gisbert, T.J., Valero Garcés, B., 1992. Type septaria-cone in cone nodules in the Stephano-Permian of the Catalan Pyrenees. Carbonates and Evaporites 7, 132139.

Avanzini, M., Contardi, P., Ronchi, A., Santi, G., 2011. Ichnosystematics of the Lower Permian invertebrate traces from the Collio and Mt. Luco Basins (North Italy). Ichnos 18, 95-113.

Besly, B.M., Collinson, J.D., 1991. Volcanic and tectonic controls of lacustrine and alluvial sedimentation in the Stephanian coal-bearing sequence of the Malpàs-Sort Basin, Catalonian Pyrenees. Sedimentology 38, 3-26.

Branney, M.J., Kokelaar, P., 2002. Pyroclastic density currents and the sedimentation of ignimbrites. Geological Society of London Memoirs 27, London. 192 pp.

Broutin, J., Gisbert, J., 1985. Entorno paleoclimático y ambiental de la flora stephanoautuniense del Pirineo Catalán. C.R. 10e Congrès Carbonifère, Madrid 1983, 5366.

Cassinis, G., Perotti, C., Ronchi, A., 2013. Geological remarks on the CarboniferousPermian continental succession of Southwestern Europe. New Mexico Museum of Natural History and Science Bulletin 60, 57-63.

Cecil, C.B., 2003. The concept of autocyclic and allocyclic controls on sedimentation and stratigraphy, emphasizing the climatic variable. In: Cecil, C.B., Edgar, N.T. (Eds.), Climate Controls on Stratigraphy. SEPM Special Publication 77, pp. 13-20.

Charbonnier, S., 2014. Synthèse sur la flore des nodules du Lagerstätte de Montceaules-Mines (Carbonifère supérieur, France). Annales de Paléontologie 100, 103-117.

Chumakov, N.M., Zharkov, M.A., 2002. Climate during Permian-Triassic biosphere reorganizations, Article 1: Climate of the Early Permian. Stratigraphy and Geological Correlation 10, 586-602. 
Cohen, K.M., Finney, S.C., Gibbard, P.L., Fan, J.-X., 2013. The ICS International Chronostratigraphic Chart (updated). Episodes 36, 199-204.

DiMichele, W.A., 2014. Wetland-dryland vegetational dynamics in Pennsylvanian ice age tropics. International Journal of Plant Sciences 175, 123-164.

DiMichele, W.A., Cecil, B., Montañez, I.P., Falcon-Lang, H.J., 2010. Cyclic changes in Pennsylvanian paleoclimate and effects on floristic dynamics in tropical Pangaea: International Journal of Coal Geology 83, 329-344.

DiMichele, W.A., Chaney, D.S., 2005. Pennsylvanian-Permian fossil floras from the Cutler Group, Cañon del Cobre and Arroyo del Agua areas, in Northern New Mexico. New Mexico Museum of Natural History and Science Bulletin 31, 26-33.

DiMichele, W.A., Lucas, S.G., Looy, C.V., Kerp, H., Chaney, D.S., 2017. Plant fossils from the Pennsylvanian-Permian transition in Western Pangea, Abo Pass, New Mexico. Smithsonian Contributions to Paleobiology 99, Washington, D.C., 40 pp.

DiMichele, W.A., Montañez, I.P., Poulsen, C.J., Tabor, N.J., 2009. Climate and vegetational regime shifts in the late Paleozoic ice age Earth. Geobiology 7, 200226.

DiMichele, W.A., Pfefferkorn, H.W., Gastaldo, R.A., 2001. Response of Late Carboniferous and Early Permian plant communities to climate change. Annual Review of Earth and Planetary Sciences 29, 461-487.

DiMichele, W.A., Tabor, N.J., Chaney, D.S., Nelson, W.J., 2006. From wetlands to wet spots: environmental tracking and the fate of Carboniferous elements in Early Permian tropical floras. In: Greb, S.F., DiMichele,W.A. (Eds.), Wetlands Through Time. Geological Society of America Special Paper 399, pp. 223-248. 
Doubinger, J., Vetter, P., Langiaux, J., Galtier, J., Broutin, J., 1995. La flore fossile du basin houiller de Saint-étienne. Mémoires du Muséum National d'Histoire Naturelle 164, Paris, $356 \mathrm{pp}$.

Eros, J.M., Montañez, I.P., Osleger, D.A., Davydov, V.I., Nemyrovska, T.I., Poletaev, V.I., Zhykalyak, M.V., 2012. Sequence stratigraphy and onlap history of the Donets Basin, Ukraine: insight into Carboniferous icehouse dynamics. Palaeogeography, Palaeoclimatology, Palaeoecology 313-314, 1-25.

Falcon-Lang, H.J., Benton, M.J., Braddy, S.J., Davis, S.J., 2006. The Pennsylvanian tropical biome reconstructed from the Joggins Formation of Nova Scotia, Canada. Journal of the Geological Society of London 163, 561-576.

Falcon-Lang, H.J., Jud, N.A., Nelson, W.J., DiMichele, W.A., Chaney, D.S., Lucas, S.G., 2011. Pennsylvanian coniferopsid forests in sabkha facies reveal the nature of seasonal tropical biome. Geology 39, 371-374.

Fielding, C.R., Frank, T.D., Isbell, J.L., 2008. The late Paleozoic ice age - a review of current understanding and synthesis of global climate patterns. In: Fielding, C.R., Frank, T.D., Isbell, J.L. (Eds.), Resolving the Late Paleozoic Ice Age in Time and Space. Geological Society of America Special Paper 441, pp. 343-354.

Galé, C., 2005. Evolución geoquímica, petrogenética y de condiciones geodinámicas de los magmatismos pérmicos en los sectores central y occidental del Pirineo. Ph.D Thesis, Universidad de Zaragoza, Zaragoza, Spain, 457 pp.

Galtier, J., Broutin, J., 2008. Floras from the red beds of the Permian Basin of Lodève (Southern France). Journal of Iberian Geology 34, 57-72.

Gand, G., 1988. Les traces de vertébrés tétrapodes du Permien francais. Ph.D Thesis, Université de Bourgogne, Dijon, France, 341 pp. 
Gand, G., Durand, M., 2006. Tetrapod footprint ichno-associations from French Permian basins. Comparisons with other Euramerican ichnofaunas. In: Lucas, S.G., Cassinis, G., Schneider, J.W. (Eds.), Non-Marine Permian Biostratigraphy and Biochronology. Geological Society of London Special Publication 265, pp. 157177.

Gand, G., Kerp, H., Parsons, C., Martínez-García, E., 1997. Palaeoenvironmental and stratigraphic aspects of the animal traces and plant remains in Spanish Permian red beds (Peña Sagra, Cantabrian Mountains, Spain). Géobios 30, 295-318.

Gascón, F., Gisbert, J., 1987. La evolución climática del Stephaniense, Pérmico y Buntsandstein del Pirineo catalán en base al estudio de paleosuelos. Cuadernos de Geología Ibérica 11, 97-114.

Gile, L.H., Peterson, F.F., Grossman, R.B., 1966. Morphological and genetic sequences of carbonate accumulation in desert soils. Soil Science 101, 347-360.

Gisbert, J., 1981. Estudio geológico-petrológico del Estefaniense-Pérmico de la Sierra del Cadí (Pirineo de Lérida): Diagénesis y sedimentología. Ph.D Thesis, Universidad de Zaragoza, Spain, 314 pp.

Gisbert, J., 1986. Els temps tardihercinians. In: Santanach, P. (Ed.), Història Natural dels Països Catalans, Geologia I. Editorial Enciclopèdia Catalana, pp. 197-242.

Gretter, N., Ronchi, A., López-Gómez, J., Arche, A., De la Horra, R., Barrenechea, J.F., Lago, M., 2015. The Late Palaeozoic-Early Mesozoic from the Catalan Pyrenees (Spain): $60 \mathrm{Myr}$ of environmental evolution in the frame of the western periTethyan palaeogeography. Earth-Science Reviews 150, 679-708.

Hartevelt, J.J.A., 1970. Geology of the upper Segre and Valira valleys, central Pyrenees, Andorra/Spain. Leidse Geologische Mededelingen 45, 349-354. 
Hounslow, M.W., Balabanov, Y.P., 2016. A geomagnetic polarity timescale for the Permian, calibrated to stage boundaries. In: Lucas, S.G., Shen, S.Z. (Eds.), The Permian timescale. Geological Society of London Special Publications 450, 43 pp. doi: $10.1144 / \mathrm{SP} 450.8$

Isbell, J.L., Henry, L.C., Gulbranson, E.L., Limarino, C.O., Fraiser, M.L., Koch, Z.J., Ciccioli, P.L., Dineen, A.A., 2012. Glacial paradoxes during the late Paleozoic ice age: evaluating the equilibrium line altitude as a control on glaciation. Gondwana Research 22, 1-19.

Kerp, H., Fichter, J., 1985. Die Makrofloren des saarpfälzischen Rotliegenden (? OberKarbon-Unter-Perm; SW-Deutschland). Mainzer geowissenschaftliche Mitteilungen 14, 159-286.

Kirschvink, J.L., 1980. The least-squares line and plane and the analysis of palaeomagnetic data. Geophysical Journal of the Royal Astronomical Society 62, 699-718.

Krauss, M.J., 1999. Paleosols in clastic sedimentary rocks: their geologic applications. Earth-Science Reviews 47, 41-70.

Lopez, M., Gand, G., Garric, J., Körner, F., Schneider, J., 2008. The playa environments of the Lodève Permian basin (Languedoc-France). Journal of Iberian Geology 34, $29-56$.

Lucas, S.G., 2007. Tetrapod footprint biostratigraphy and biochronology. Ichnos 14, 538.

Machette, M.N., 1985. Calcic soils of the southwestern United States. In: Weide, D.L. (Ed.), Soil and Quaternary Geology of the Southwestern United States. Special Paper, Geological Society of America 203, pp. 1-21. 
Mack, G.H., James, W.C., Monger, H.C., 1993. Classification of paleosols. Geological Society of America Bulletin 105, 129-136.

Mack, G.H., Leeder, M., Perez-Arlucea, M., Bailey, B.D.J., 2003. Early Permian siltbed fluvial sedimentation in the Orogrande basin of the Ancestral Rocky Mountains, New Mexico, USA. Sedimentary Geology 160, 159-178.

Marchetti, L., 2016. New occurrences of tetrapod ichnotaxa from the Permian Orobic Basin (Northern Italy) and critical discussion of the age of the ichnoassociation. Papers in Palaeontology 2, 363-386.

Martí, J., 1983. La formación volcánica estefaniense Erill Castell (Pirineo de Lérida). Acta Geológica Hispánica 18, 27-33.

Martí, J., 1996. Genesis of crystal-rich volcaniclastic facies in the Permian red beds of the Central Pyrenees (NE Spain). Sedimentary Geology 106, 1-19.

Martí, J., Mitjavila, J., 1988. El volcanismo tardihercínico del Pirineo Catalán, II: caracterización de la actividad explosiva. Acta Geològica Hispànica 23, 21-31.

Martín-Closas, C., Galtier, J., 2005. Plant taphonomy and paleoecology of late Pennsylvanian intramontane wetlands in the Graissessac-Lodève basin (Languedoc, France). Palaios 20, 249-265.

Martín-Closas, C., Gomez, B., 2004. Taphonomie des plantes et interprétations paléoécologiques. Une synthèse. Géobios 37, 65-88.

Martín-Closas, C., Martínez-Roig, D., 2007. Plant taphonomy and palaeoecology of Stephanian limnic wetlands in the eastern Pyrenees (Catalonia, Spain). Comptes Rendus Palevol 6, 437-449.

Mey, P.H.W., Nagtegaal, P.J.C., Roberti, K.J., Hartevelt, J.J.A., 1968. Lithostratigraphic subdivision of post-Hercynian deposits in the south-central Pyrenees, Spain. Leidse Geologische Mededelingen 44, 221-228. 
Miall, A.D., 1985. Architectural-element analysis: a new method of facies analysis applied to fluvial deposits. Earth-Science Reviews 22, 261-308.

Miall, A.D., 1992. Alluvial deposits. In: Walker, R.G., James, N.P. (Eds.), Facies Models. Geological Association of Canada Publications, pp. 119-142.

Michel, L.A., Tabor, N.J., Montañez, I.P., 2016. Paleosol diagenesis and its deep-time paleoenvironmental implications, Pennsylvanian-Permian Lodève Basin, France. Journal of Sedimentary Research 86, 813-829.

Michel, L.A., Tabor, N.J., Montañez, I.P., Schmitz, M.D., Davydov, V.I., 2015. Chronostratigraphy and Paleoclimatology of the Lodève Basin, France: Evidence for a pan-tropical aridification event across the carboniferous-permian boundary. Palaeogeography, Palaeoclimatology, Palaeoecology 430, 118-131.

Montañez, I.P., McElwain, J.C., Poulsen, C.J., White, J.D., DiMichele, W.A., Wilson, J.P., Griggs, G., Hren, M.T., 2016. Climate $p \mathrm{CO}_{2}$ and terrestrial carbon cycle linkages during late Palaeozoic glacial-interglacial cycles. Nature Geoscience 9, $824-831$.

Montañez, I.P., Poulsen, C.J., 2013. The late Paleozoic ice age: An evolving paradigm. Annual Review of Earth and Planetary Sciences 41, 629-656.

Montañez, I.P., Tabor, N.J., Niemeier, D., DiMichele, T.D., Frank, C.R., Fielding, J.L., Isbell, J.L., Birgenheier, L.P., Rygel, M.C., 2007. $\mathrm{CO}_{2}$-forced climate instability and linkages to tropical vegetation during Late Paleozoic deglaciation. Science 315, 87-91.

Mujal, E., Fortuny, J., Bolet, A., Oms, O., López, J.Á., 2017. An archosauromorph dominated ichnoassemblage in fluvial settings from the late Early Triassic of the Catalan Pyrenees (NE Iberian Peninsula). PLoS ONE 12, e0174693. doi: 10.1371/journal.pone.0174693 
Mujal, E., Fortuny, J., Oms, O., Bolet, A., Galobart, À., Anadón, P., $2016 a$. Palaeoenvironmental reconstruction and early Permian ichnoassemblage from the NE Iberian Peninsula (Pyrenean Basin). Geological Magazine 153, 578-600.

Mujal, E., Fortuny, J., Pérez-Cano, J., Dinarès-Turell, J., Ibáñez-Insa, J., Oms, O., Vila, I., Bolet, A., Anadón, P., in press. Integrated multi-stratigraphic study of the Coll de Terrers late Permian-Early Triassic continental succession from the Catalan Pyrenees (NE Iberian Peninsula): A geologic reference record for equatorial Pangaea. Global and Planetary Change. doi: 10.1016/j.gloplacha.2017.10.004

Mujal, E., Gretter, N., Ronchi, A., López-Gómez, J., Falconnet, J., Diez, J.B., De la Horra, R., Bolet, A., Oms, O., Arche, A., Barrenechea, J.F., Steyer, J.-S., Fortuny, J., 2016b. Constraining the Permian/Triassic transition in continental environments: Stratigraphic and paleontological record from the Catalan Pyrenees (NE Iberian Peninsula). Palaeogeography, Palaeoclimatology, Palaeoecology 445, 18-37.

Nagtegaal, P.J.C., 1969. Sedimentology, paleoclimatology, and diagenesis of postHercynian continental deposits in the south-central Pyrenees, Spain. Leidse Geologische Mededelingen 42, 143-238.

Opluštil, S., Jirásek, J., Schmitz, M., Matýsek, D., 2017a. Biotic changes around the radioisotopically constrained Carboniferous-Permian boundary in the Boskovice Basin (Czech Republic). Bulletin of Geosciences 92, 95-122.

Opluštil, S., Šimůnek, Z., Pšenička, J., Bek, J., Libertín, M., 2017b. A 25 million year macrofloral record (Carboniferous-Permian) in the Czech part of the Intra-Sudetic Basin; biostratigraphy, plant diversity and vegetation patterns. Review of Palaeobotany and Palynology 244, 241-273. 
Opluštil, S., Šimůnek, Z., Zajíc, J., Mencl, V., 2013. Climatic and biotic changes around the Carboniferous/Permian boundary recorded in the continental basins of the Czech Republic. International Journal of Coal Geology 119, 114-151.

Parés, J.M., 1988. Estudio paleomagnético de las rocas tardihercinianas de la Cadena Costero Catalana: primeros resultados. Cuadernos de Geología Ibérica 12, 171-179.

Pereira, M.F., Castro, A., Chichorro, M., Fernández, C., Díaz-Alvarado, J., Martí, J., Rodríguez, C., 2014. Chronological link between deep-seated processes in magma chambers and eruptions: Permo-Carboniferous magmatism in the core of Pangaea (Southern Pyrenees). Gondwana Research 25, 290-308.

Peyser, C.E., Poulsen, C.J., 2008. Controls on Permo-Carboniferous precipitation over tropical Pangaea: A GCM sensitivity study. Palaeogeography, Palaeoclimatology, Palaeoecology 268, 181-192.

Phillips, T.L., Galtier, J., 2005. Evolutionary and ecological perspectives of Late Paleozoic ferns part I. Zygopteridales. Review of Palaeobotany and Palynology $135,165-203$.

Roberts, A.P., Cui, Y., Verosub, K.L., 1995. Wasp-waisted hysteresis loops: Mineral magnetic characteristics and discrimination of components in mixed magnetic systems. Journal Geophysical Research 100(B9), 17909-17924.

Roscher, M., Schneider, J.W., 2006. Permo-Carboniferous climate: Early Pennsylvanian to Late Permian climate development of central Europe in a regional and global context. In: Lucas, S.G., Cassinis, G., Schneider, J.W. (Eds.), Non-Marine Permian Biostratigraphy and Biochronology. Geological Society of London Special Publication 265, pp. 95-136.

Rosenau, N.A., Tabor, N.J., Elrick, S.D., Nelson, W.J., 2013. Polygenetic history of paleosols in Middle-Upper Pennsylvanian cyclothems of the Illinois Basin, U.S.A.: 
Part II. Integrating geomorphology, climate, and glacioeustasy. Journal of Sedimentary Research 83, 637-668.

Saura, E., Teixell, A., 2006. Inversion of small basins: effects on structural variations at the leading edge of the Axial Zone antiformal stack (Southern Pyrenees, Spain). Journal of Structural Geology 28, 1909-1920.

Schneider, J.W., Körner, F., Roscher, M., Kroner, U., 2006. Permian climate development in the northern peri-Tethys area - The Lodève basin, French Massif Central, compared in a European and global context. Palaeogeography, Palaeoclimatology, Palaeoecology 240, 161-183.

Sheldon, N.D., Tabor, N.J., 2009. Quantitative paleoenvironmental and paleoclimatic reconstruction using paleosols. Earth-Science Reviews 95, 1-52.

Simon, S.S.T., Gibling, M.R., DiMichele, W.A., Chaney, D.S., Looy, C.V., Tabor, N.J., 2016. An abandoned-channel fill with exquisitely preserved plants in redbeds of the Clear Fork Formation, Texas, USA: An early Permian water-dependent habitat on the arid plains of Pangea. Journal of Sedimentary Research 86, 944-964.

Soil Survey Staff, 2014. Keys to Soil Taxonomy. United States Department of Agriculture, Natural Resources Conservation Service, 372 pp.

Speksnijder, A., 1985. Anatomy of a strike-slip fault controlled sedimentary basin, Permian of the Southern Pyrenees, Spain. Sedimentary Geology 44, 179-223.

Tabor, N.J., DiMichele, W.A., Montañez, I.P., Chaney, D.S., 2013. Late Paleozoic continental warming of a cold tropical basin and floristic change in western Pangea. International Journal of Coal Geology 119, 177-186.

Tabor, N.J., Montañez, I.P., 2002. Shifts in late Paleozoic atmospheric circulation over western equatorial Pangean: Insights from pedogenic $\mathrm{d}^{18} \mathrm{O}$ compositions. Geology $30,1127-1130$. 
Tabor, N.J., Montañez, I.P., 2004. Morphology and distribution of fossil soils in the Permo-Pennsylvanian Witchita and Bowie Groups, north-central Texas, USA: implications for western equatorial Pangean palaeoclimate during icehousegreenhouse transition. Sedimentology 51, 851-884.

Tabor, N.J., Montañez, I.P., Scotese, C.R., Poulsen, C.J., Mack, G.H., 2008. Paleosol archives of environmental and climatic history in paleotropical Western Euramerica during the latest Pennsylvanian through Early Permian. In: Fielding, C.R., Frank, T.D., Isbell, J.L. (Eds.), Resolving the Late Paleozoic Ice Age in Time and Space. Geological Society of America Special Paper 441, pp. 291-304.

Tabor, N.J., Myers, T.S., 2015. Paleosols as indicators of paleoenvironment and paleoclimate. Annual Review of Earth and Planetary Sciences 43, 333-361.

Tabor, N.J., Poulsen, C.J., 2008. Palaeoclimate across the Late Pennsylvanian-Early Permian tropical palaeolatitudes: a review of climate indicators, their distribution, and relation to palaeophysiographic climate factors. Palaeogeography, Palaeoclimatology, Palaeoecology 268, 293-310.

Talens, J., Wagner, R.H., 1995. Stratigraphic implications of late Carboniferous and early Permian megafloras in Lérida, south-central Pyrenees; comparison with the Cantabrian Mountains. Coloquios de Paleontología 47, 177-192.

Uhl, D., Jasper, A., 2016. New data on the macroflora of the basal Rotliegend Group (Remigiusberg Formation; Gzhelian) in the Saar-Nahe Basin (SW-Germany). Fossil Imprint 72, 239-250.

Valero Garcés, B.L., 1993. Lacustrine deposition and related volcanism in a transtensional tectonic setting: Upper Stephanian-Lower Autunian in the AragónBéarn Basin, western Pyrenees (Spain-France). Sedimentary Geology 83, 133-160. 
Van der Voo, R., 1993. Paleomagnetism of the Atlantic, Tehys and Iapetus Oceans. Cambridge University Press, Cambridge, 411 pp.

Voigt, S., Haubold, H., 2015. Permian tetrapod footprints from the Spanish Pyrenees. Palaeogeography, Palaeoclimatology, Palaeoecology 417, 112-120.

Voigt, S., Lagnaoui, A., Hminna, A., Saber, H., Schneider, J.W., 2011. Revisional notes on the Permian tetrapod ichnofauna from the Tiddas Basin, central Morocco. Palaeogeography, Palaeoclimatology, Palaeoecology 302, 474-483.

Voigt, S., Lucas, S.G., 2016. Outline of a Permian tetrapod footprint ichnostratigraphy. In: Lucas, S.G., Shen, S.Z. (Eds.), The Permian timescale. Geological Society of London Special Publications 450, 18 pp. doi: 10.1144/SP450.10

Voigt, S., Lucas, S.G., Buchwitz, M., Celeskey, M., 2013. Robledopus macdonaldi, a new kind of basal eureptile footprint from the Early Permian of New Mexico. New Mexico Museum of Natural History and Science Bulletin 60, 445-459.

Wagner, R.H., Álvarez-Vázquez, C., 2010. The Carboniferous floras of the Iberian Peninsula: a synthesis with geological connotations. Review of Palaeobotany and Palynology 162, 239-324.

Zijderveld, J.D.A., 1967. AC demagnetisation of rock: analysis of results. In: Collinson, D.W., Creer, K.M., Runcorn, S.K. (Eds.), Methods in palaeomagnetism. Elsevier, Amsterdam, pp. 254-286.

\section{Figure Captions}

Figure 1. Geographical and geological setting. (A) European situation and regional geology. (B) Geological map of the studied area based on field cartography and 
photointerpretation; the area around La Mola d'Amunt village is updated from Mujal et al. (2016a, 2017).

Figure 2. Stratigraphy of the studied sections. Paleosols are ordered from relatively humid (left) to relatively arid (right) climates based on Tabor et al. (2008). Note that Coll de Sas vertical scale is four times that of Les Esglésies. Numbers of Les Esglésies ignimbrites are those from Figure 1. Detailed sections of Coll de Sas and Les Esglésies are found as supplementary material (Supplementary Data S1 and S2, respectively).

Figure 3. Grey Unit. (A) Overview of the SE outcrop at Coll de Sas exposing coals with interbedded relatively small meandering sandstone deposits. (B) Braided deposits at the base of Coll de Sas composed of andesitic pebbles (detail in B'). (C) Set of lateral accretions building point bars of meandering systems at Coll de Sas section; floodplain deposits are composed of carbonaceous mudstones and overbanks are composed of sandstones.

Figure 4. Grey Unit pedotypes. (A, B) Coal intervals (horizons O, Histosol) at the top of sandstone channels at Coll de Sas (A) and Les Esglésies (B). (C) Cracked nodule with ferric crusts from a sandstone overbank at Coll de Sas. (D) Ferric nodules (white arrows) defining the stratification within floodplain mudstones above a sandstone channel.

Figure 5. Transition Unit at Coll de Sas (A-I) and Les Esglésies (J) section. (A) General aspect of sandstones from small meandering and overbank deposits at the basal portion of the unit. (B) Mudstones displaying large scale slickensides (Vertisols). (C) 
Mudstones with slickensides and large septarian nodules (gleyed Vertisols) at the middle portion of the unit. (D, E) Examples of septarian nodules. (F, G) Mudstones with slickensides and carbonate nodules (detail of sliding surface in F') at the topmost portion of the unit. (H) Alternation of lacustrine dolostones, limestones, coal and mudstones (note the minor fault folding the strata). (I) Laminated sandstones and microbreccias from the upper portion of the section.

Figure 6. Lower Red Unit at Coll de Sas (A) and Les Esglésies (B-I). (A) Ignimbrite breccia penetrating red mudstones at the basalmost portion of the unit. (B) Ignimbrites projecting out on the relief (see numbers in Figs. 1, 2); distance between ignimbrites 2 and 6 is of ca. $125 \mathrm{~m}$. (C) Volcanic breccia with erosive base (dashed line) and mudstones derived from runoff water flows at the topmost part (arrows). (D) Volcanic breccia with lithic clasts, including limestones from calcretes (arrow). (E) Fining upwards sandstone-grained volcaniclastic (ignimbrite) with cross stratification and soft pebbles. (F, G) Grey cinerites from $161 \mathrm{~m}(\mathrm{~F})$ and $732-733 \mathrm{~m}(\mathrm{G})$ of the measured section. (H) Lateral accretions (meandering deposits) composed of reworked volcaniclastic deposits from $358 \mathrm{~m}$ to $365 \mathrm{~m}$ of the measured section. (I) Thin section of a cracked red mudstone (cracks infilled with sparry calcite) preserving ooid-like concretions. Top to the $\mathrm{S}$ in all photos.

Figure 7. Lower Red Unit calcic pedotypes from Les Esglésies section (stratigraphic height indicated). (A) Stacking of profiles Bk-Bkk (Calcisols; 105.5-109.5 m). (B) Succession of horizons Bk and Bkk (some nodules coalesced forming incipient calcretes; 66-67 m). (C) Horizon Bk (Calcisol; 74 m). (D, E) Profiles Bkk-Bkkm with reddish/purplish and gleyed (greenish) mudstones $(55-56 \mathrm{~m})$, nodules display sliding 
surfaces. (F) Channelized and amalgamed calcretes (concave part to the right of the photo) (horizons Bkkm; 44-45 m). (G) Carbonate septarian nodules (detail in G') defining stratification and interbedded with mudstones (around $183.5 \mathrm{~m})$. (H) Large rhizolith (around $89 \mathrm{~m}$ ). (I) Greenish root traces (Rt, horizon A) above carbonate nodules (Cn, horizon Bkk) ( 95 m). (J) Tiny carbonate nodules (Protosol) in a silty mudstone $(397 \mathrm{~m})$, hammer is $30 \mathrm{~cm}$ long. Top to the $\mathrm{S}$ in all photos.

Figure 8. Lower Red Unit pedotypes (A-G) and plant remains (H, I). (A, B) Vertisols below ignimbrite 3: gleyed calcic Vertisol $\sim 2.5 \mathrm{~km}$ eastwards from the measured section (A) and gleyed Vertisol where the section was measured (B). (C) Greenish, horizontal root traces (Vertisol; $183.5 \mathrm{~m}$ ). (D) Horizons with slickensides, greenish mottles and carbonate nodules (calcic Vertisol; $191.5 \mathrm{~m}$ ). (E, F) Strongly gleyed mudstones with carbonate nodules (E: horizons Bkg at 587.5-590 m; F: horizon Bkw at $202 \mathrm{~m}$ ). (G) Root traces in a silty sandstone (horizon A; Protosol; $277 \mathrm{~m}$ ). (H, I) Impressions of Walchia-like plants from the meandering fluvial interval at $170-180 \mathrm{~m}$ of the measured section. Hammer is $30 \mathrm{~cm}$ long. Top to the $\mathrm{S}$ in all photos.

Figure 9. Plant remains (horsetails and ferns) from the Coll de Sas locality. (A) Leafy whorl of Annularia sphenophylloides, level $43.00 \mathrm{~m}$ (IPS-103135). (B) Annularia stellata axis bearing three leafy whorls attached, level $30.20 \mathrm{~m}$ (IPS-103120). (C) Articulated stem of Sphenophyllum oblongifolium bearing leafy whorls attached, level $0.2 \mathrm{~m}$ (IPS-103100). (D) Leafy whorl of Sphenophyllum sp., level $23.40 \mathrm{~m}$ (IPS103109). (E) Articulated stem of Sphenophyllum sp., level 34.60 m (IPS-103129). (F) Calamitalean cone of Calamostachys sp., level 28.40 m (IPS-103114). (G) Sporangium of an indeterminate sphenophyte, level 32.70 m (IPS-103126). (H) Detached pinna of 
Nemejcopteris feminaeformis, level 28.40 m (IPS-103115). (I) Detached pinna of Pecopteris cf. arborescens, level 15.65 m (IPS-103102). (J) Isolated pinna of Pecopteris cf. robustissima with an isolated leafy whorl of Annularia sphenophylloides, level 42.50 m (IPS-103133). (K) Fragment of pinna of Pecopteris cf. jongmansii, level $32.70 \mathrm{~m}$ (IPS-103126). (L) Partial pinna of Polymorphopteris polymorpha, level 23.40 m (IPS103109). (M) Fragment of a likely frond of Polymorphopteris polymorpha, level 34.20 m (IPS-103127). (N) Detached pinna of Diplazites emarginatus, level $42.50 \mathrm{~m}$ (IPS103133). (O) Apical end of a D. emarginatus pinna collected in the Coll de Sas area showing details of venation.

Figure 10. Plant remains (pteridosperms, cordaitales and licophytes) from the Coll de Sas locality. (A) Fragment of pinna of Odontopteris brardii collected during the prospecting works. (B) Detail of pinnulae and venation of the same specimen. (C) Fragment of pinna of Odontopteris cf. cantabrica, level 15.65 m (IPS-103102). (D) Fragment of pinna of Callipteridium zeilleri, level 32.70 m (IPS-103126). (E) Detached pinnula of Neuropteris sp., level 33.40 m (Coll de Sas ESE, IPS-103143). (F) Fragment of leaf with parallelodromous venation of a Cordaites sp., level 32.60 m (IPS-103125). (G) Fragment of narrow, ribbon-shaped leaf with parallelodromous venation likely belonging to Poacordaites, level 42.50 m (IPS-103133). (H) Partial Sigillariostrobus sp. cone, level $17.30 \mathrm{~m}$ (Coll de Sas W, IPS-103139); scale equals to $1 \mathrm{~cm}$.

Figure 11. Taphonomical features of plant megafossils from Coll de Sas locality. (A) Well preserved Pecopteris sp. frond bearing sori on the reverse of pinnulae, level 29.70 $m$ (IPS-103118). (B) Hand rock specimen showing a dense accumulation of fragmentary plant remains preserved in different layers, level 34.20 m (IPS-103127). 
(C) Sparse, detached whorls of Annularia sphenophylloides, level $42.50 \mathrm{~m}$ (IPS103133). (D) Fragments of detached fern pinnae randomly orientated, level $42.50 \mathrm{~m}$ (IPS-103133). (E) Large stem probably belonging to a calamitale.

Figure 12. Lithologic log with ChRM declination and inclination data for Coll de Sas and Les Esglésies sections; VGP latitude is also provided for Les Esglésies section. The interpreted polarity for each section is discussed in the text.

Figure 13. Correlation of the $\sim 1000 \mathrm{~m}$ thick composite section to the most recent International Chronostratigraphic Chart (Cohen et al., 2013). Correlation of the LRU ignimbrite to $290 \mathrm{Ma}$ is based on stratigraphic data by Martí (1996) and zircon dating by Pereira et al. (2014). The upper boundary of the LRU is suggested to be in the middle Kungurian, though the dashed line indicates uncertainty. Kasim.: Kasimovian. S.B. and S.C.: Stephanian B and C, respectively (according to Wagner and ÁlvarezVázquez, 2010). Guad.: Guadalupian (middle Permian). T.F.: tetrapod footprints intervals. BUNT: Buntsandstein. Paleoclimatic trend is derived from the pedotypes succession, the associated climate to each pedotype is based in Tabor et al. (2008), Tabor and Poulsen (2008) and Michel et al. (2015) and references therein. Green shading in the climatic trend denotes intervals of seasonality evidenced by vertic pedotypes. Paleoenvironmental reconstructions of the studied successions (not scaled): note the predominance of wet seasons during the late Carboniferous and of dry seasons during the early Permian; preliminary paleoenvironmental distribution of late Carboniferous plants based on Martín-Closas and Martínez Roig (2007) (see plant silhouettes in Supplementary Fig. S1); paleoenvironmental distribution of early Permian fauna based on Mujal et al. (2016a). 


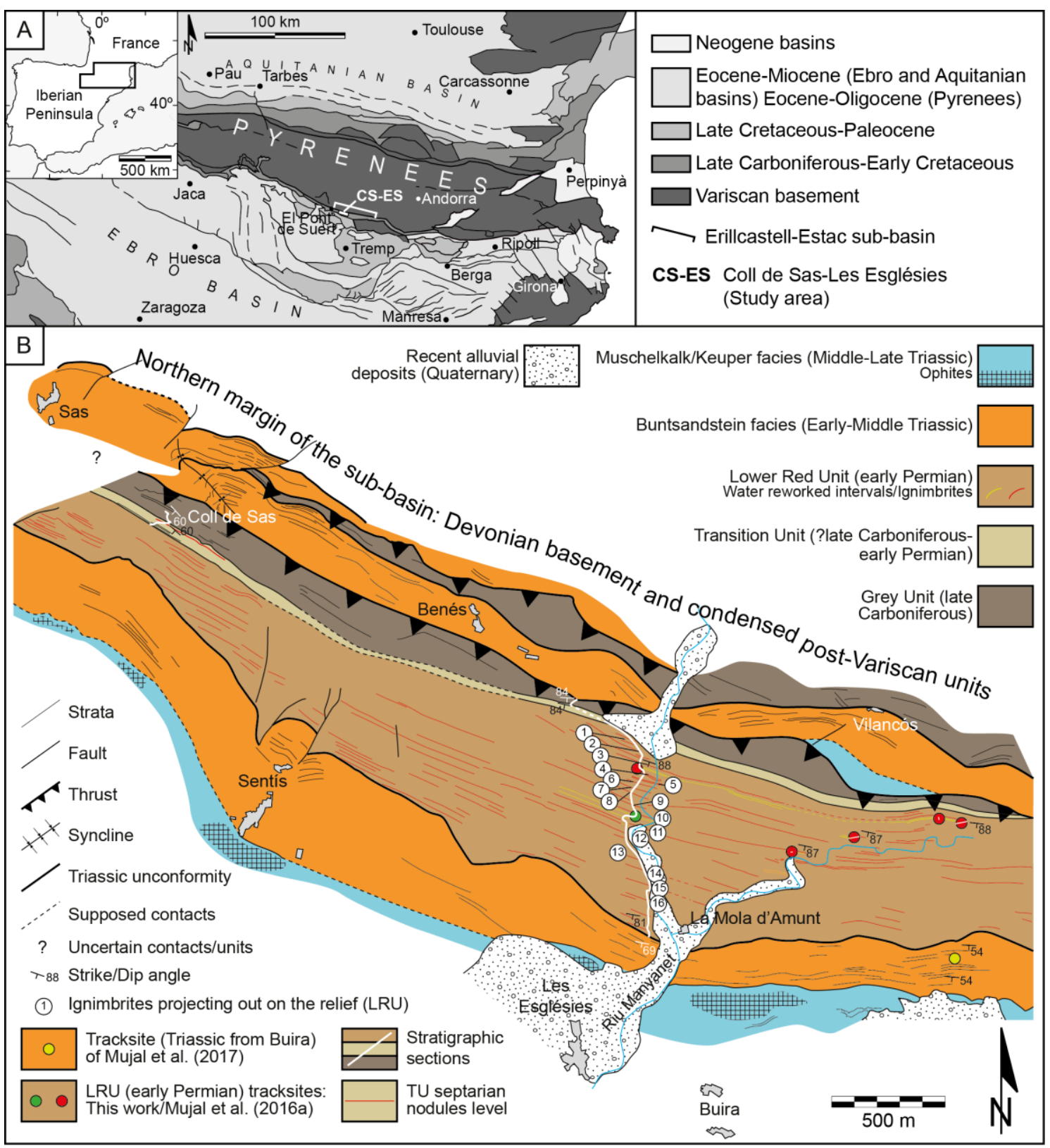

Figure 1 


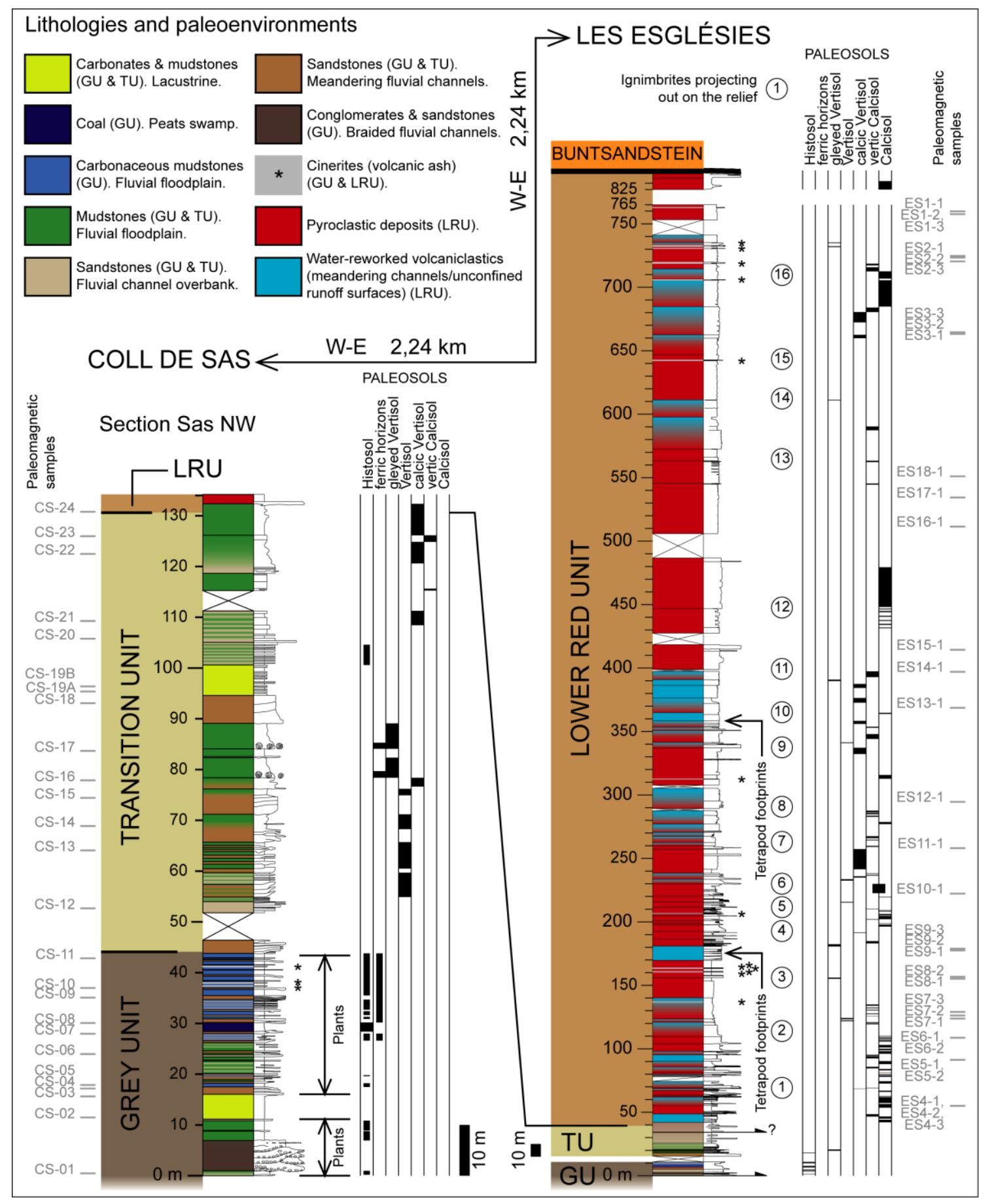

Figure 2 

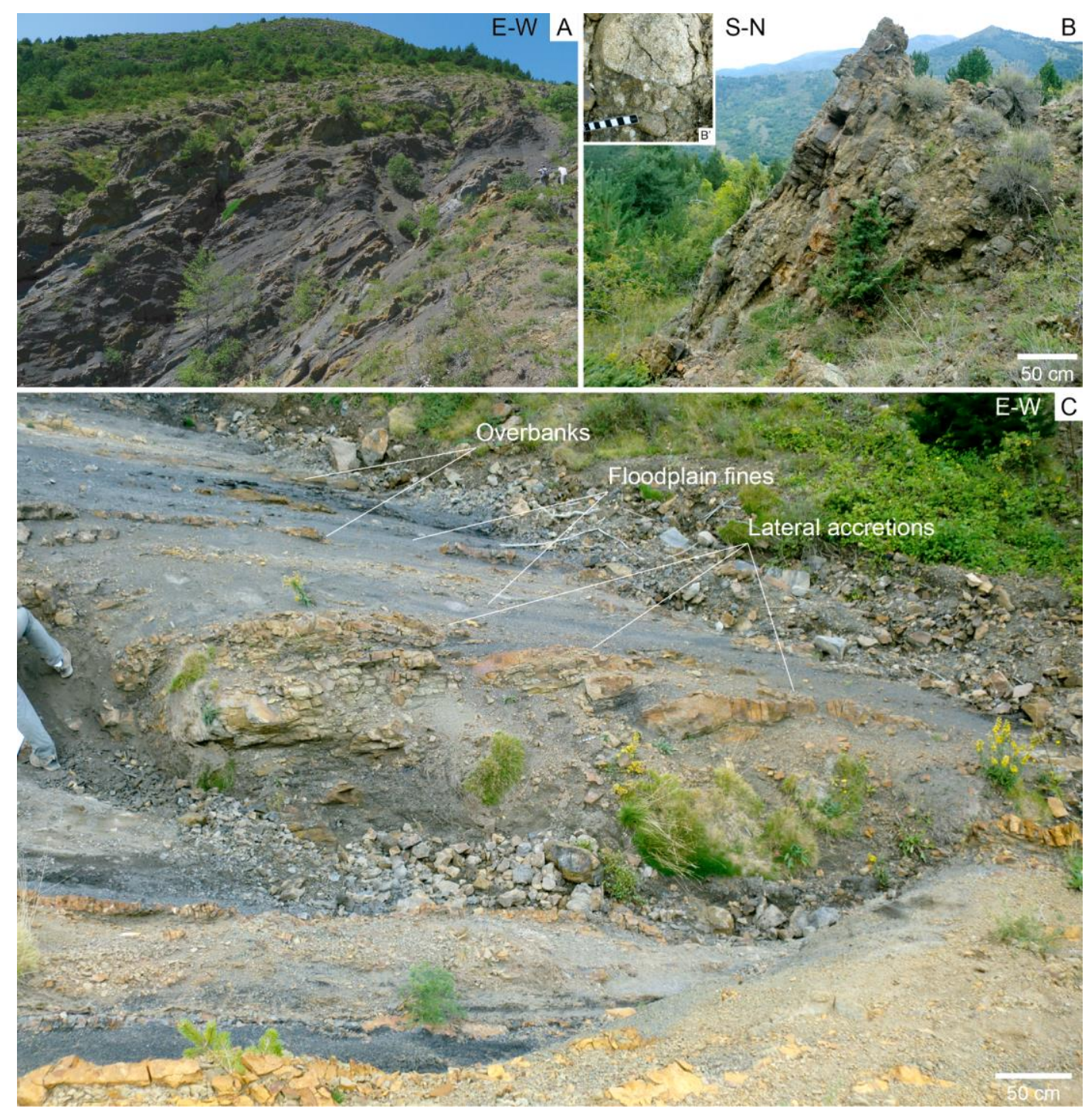

Figure 3 

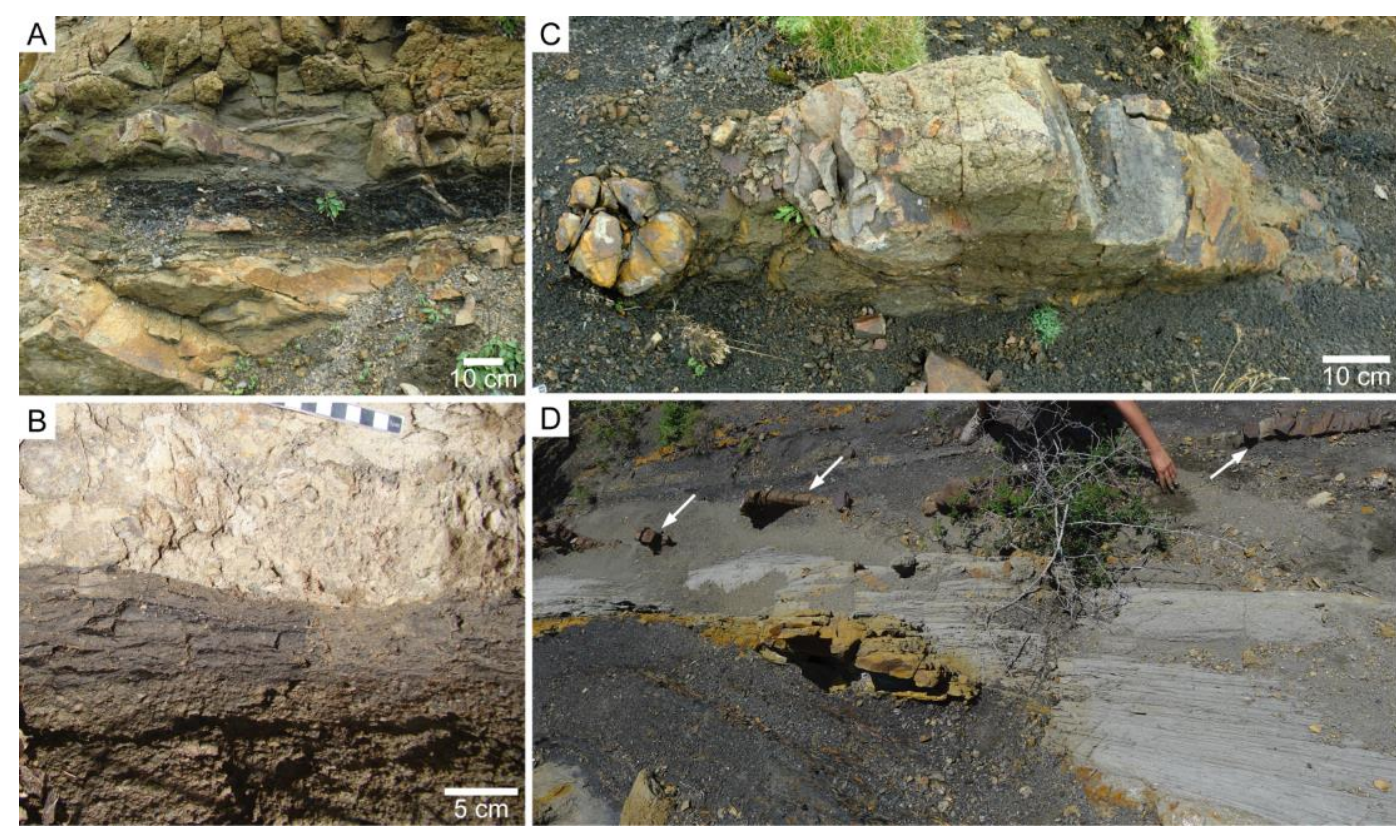

Figure 4 

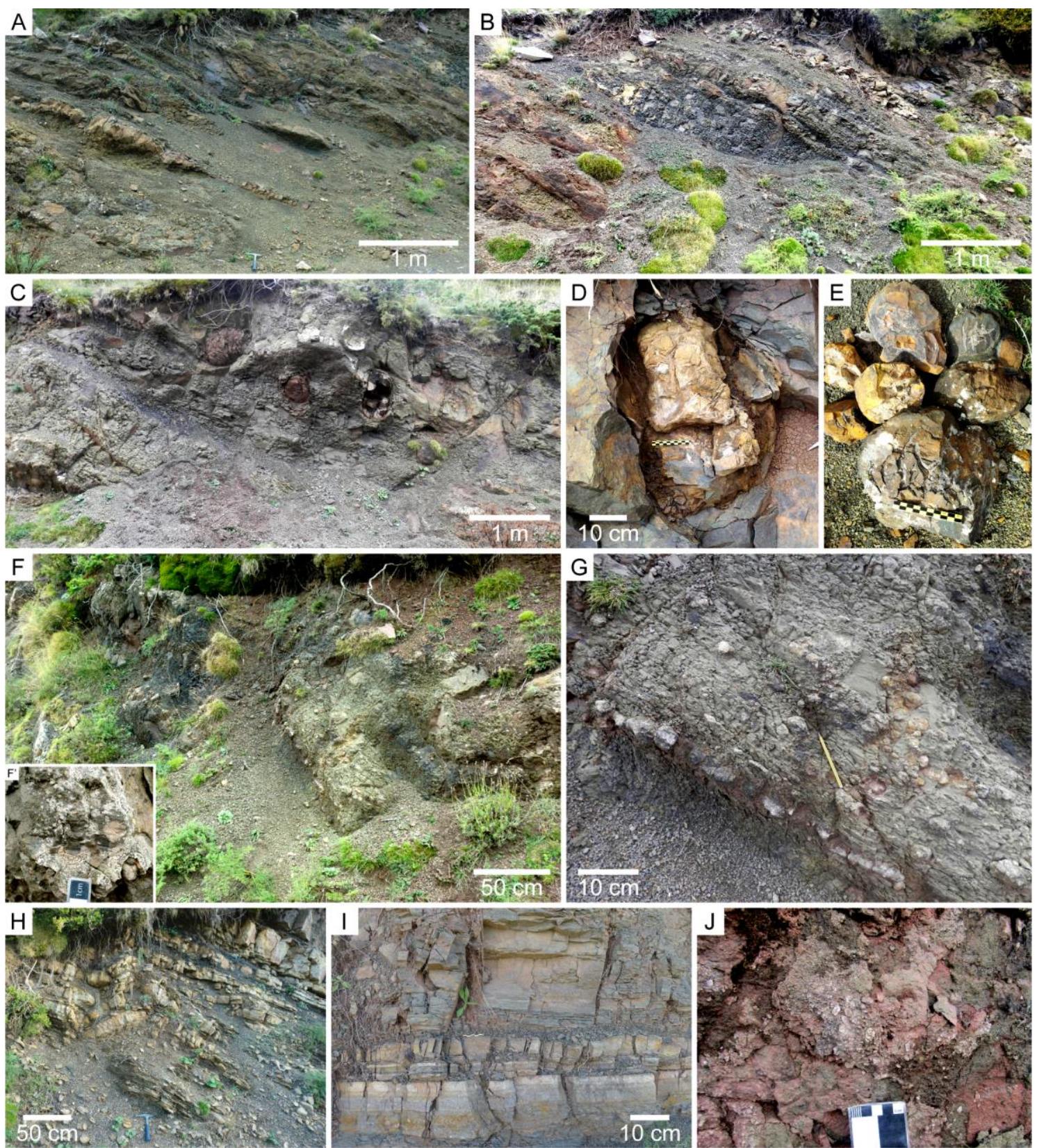

Figure 5 

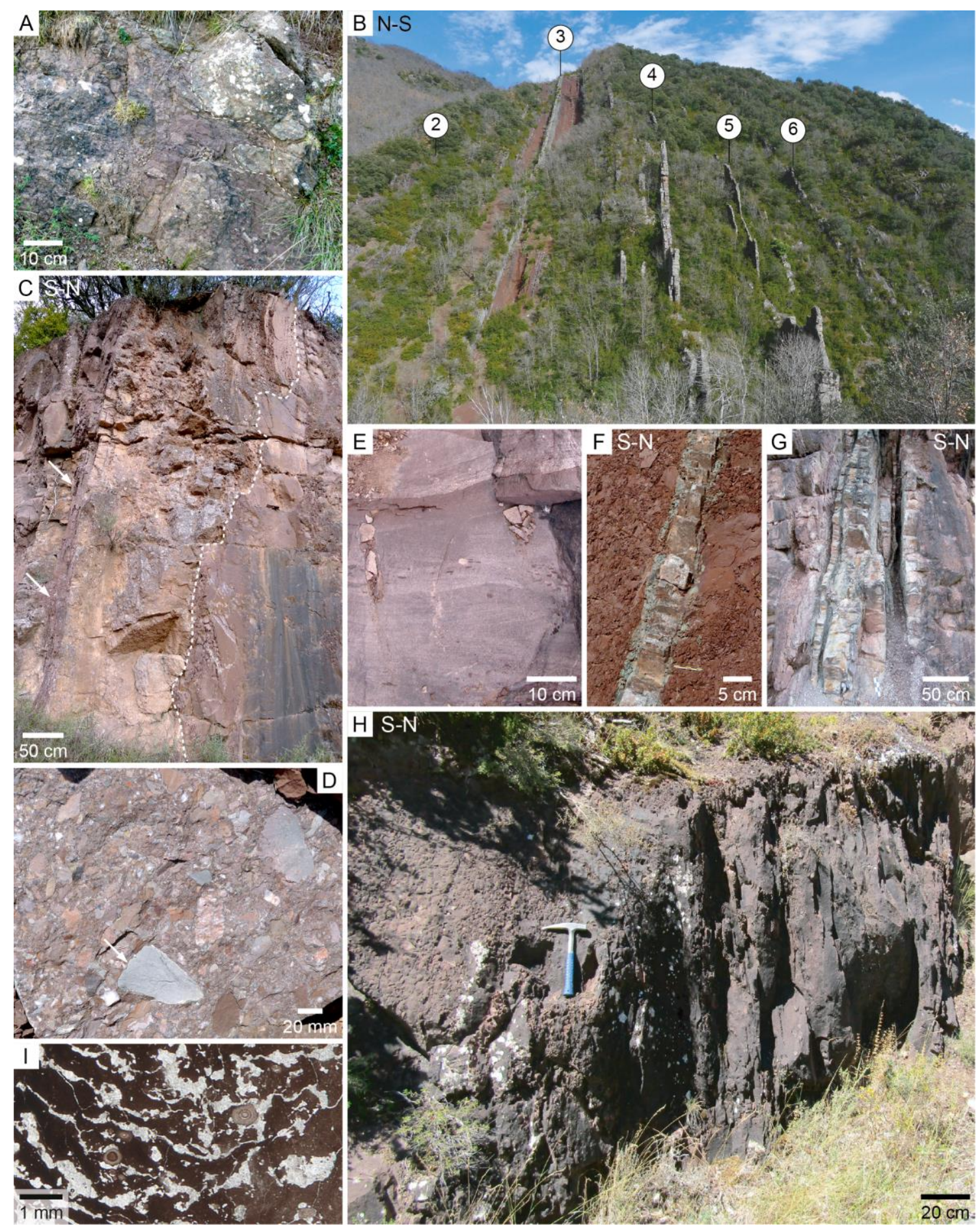

Figure 6 


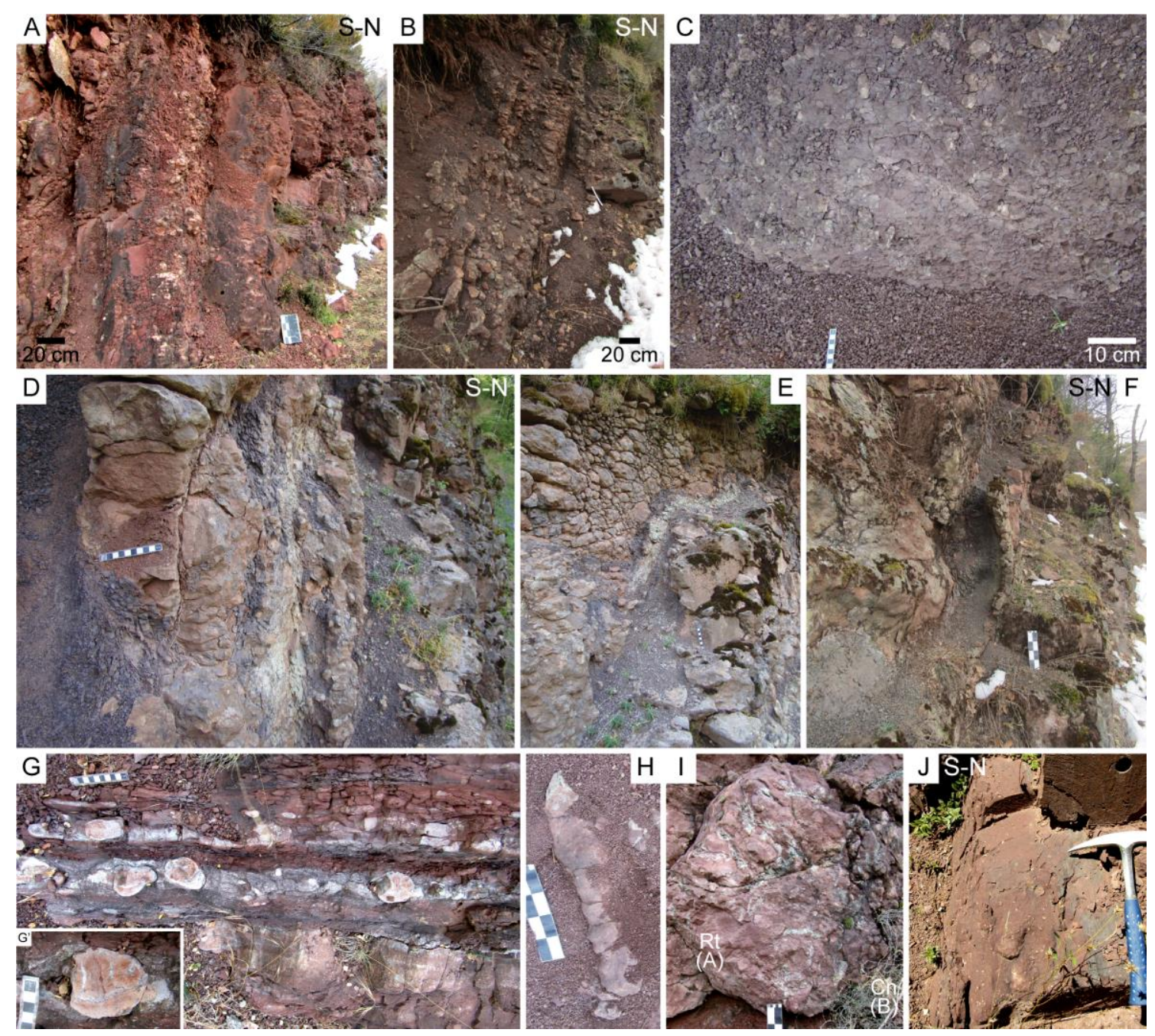

Figure 7 


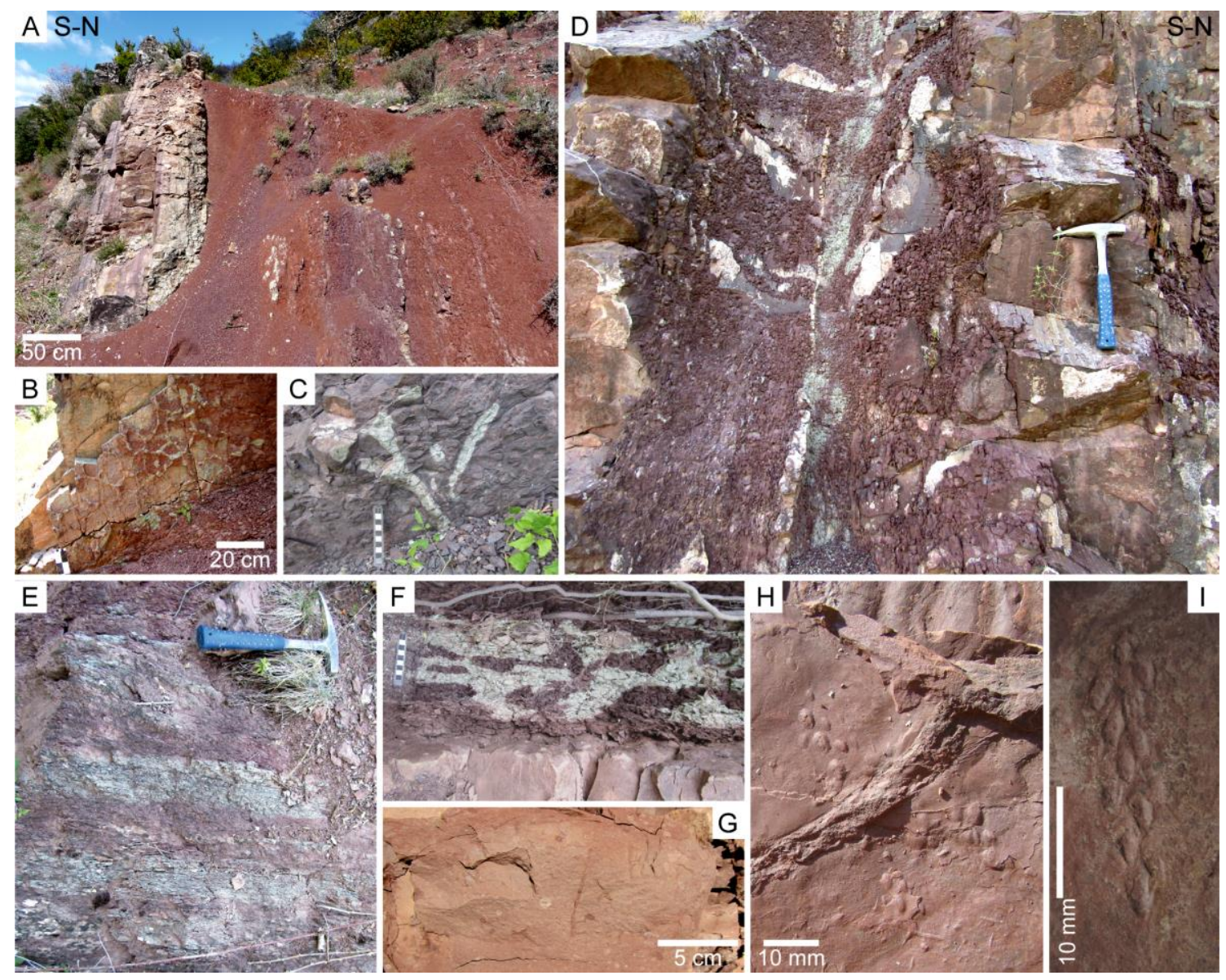

Figure 8 

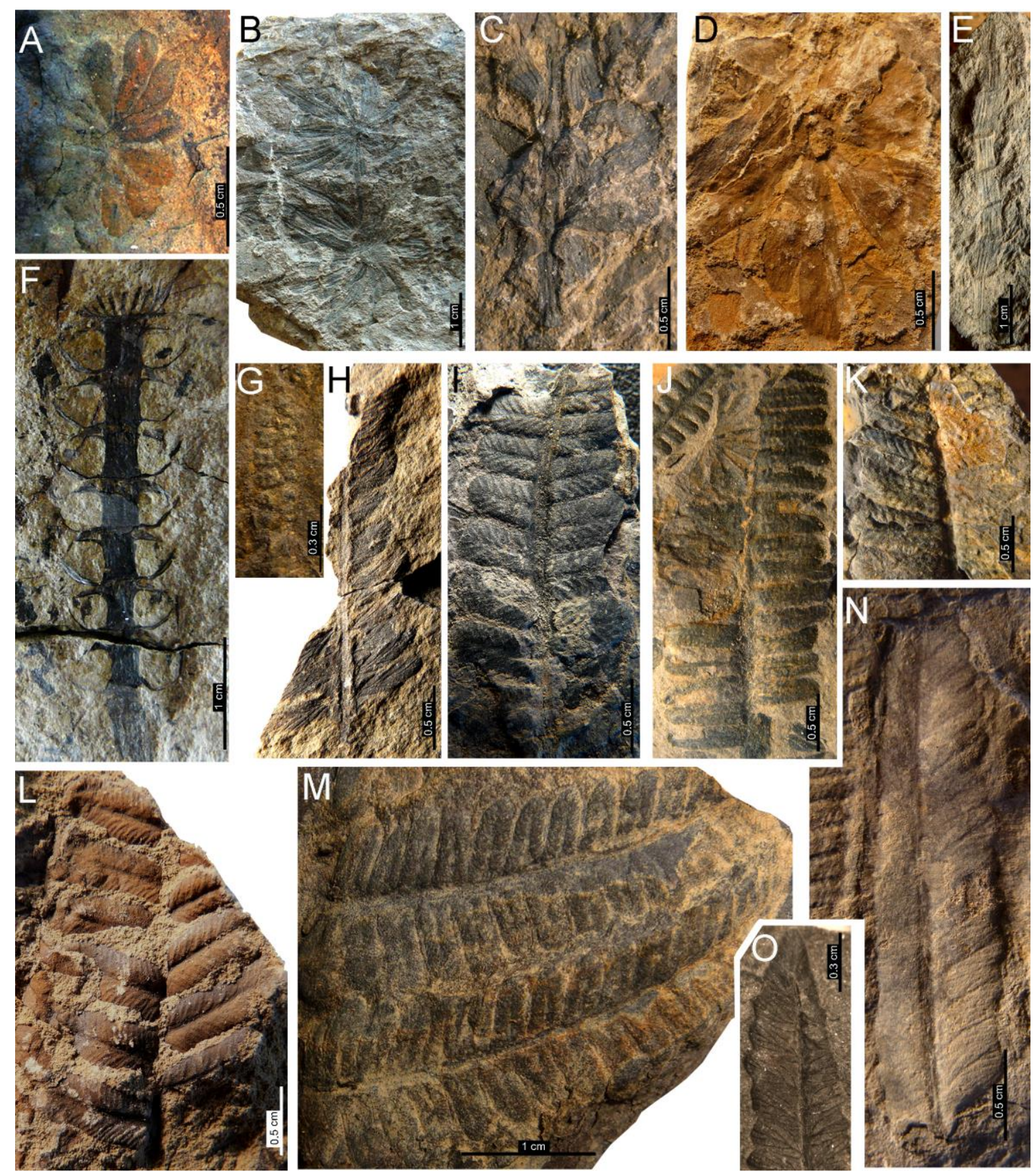

Figure 9 

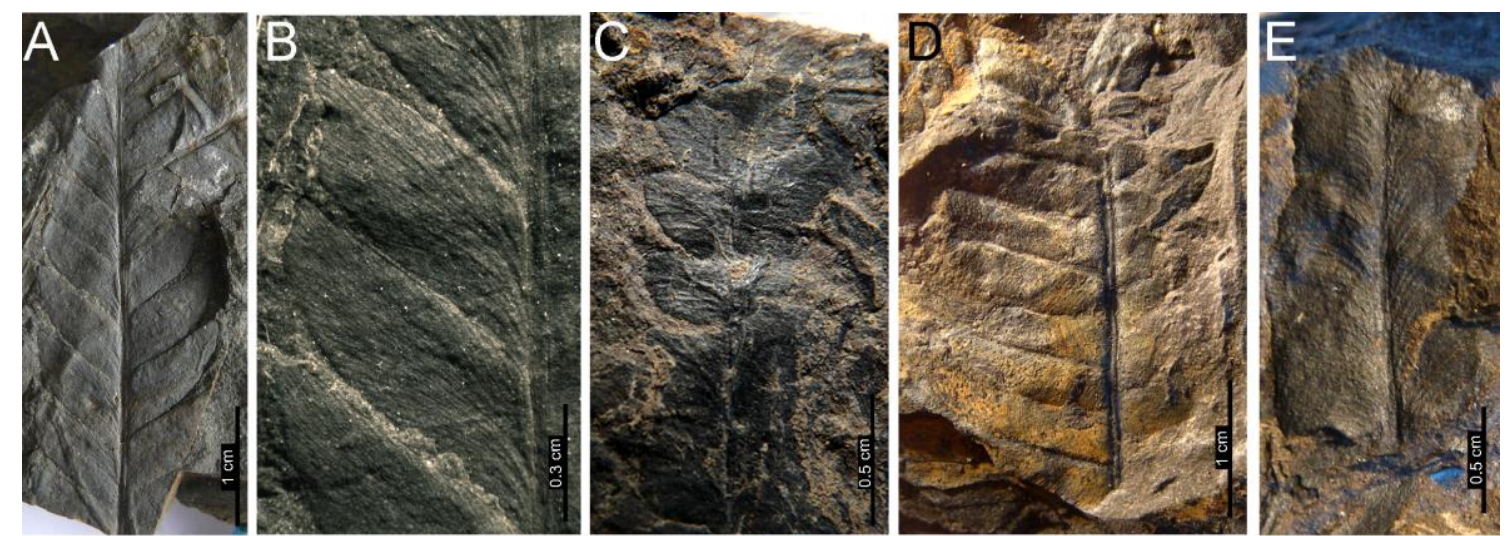

F
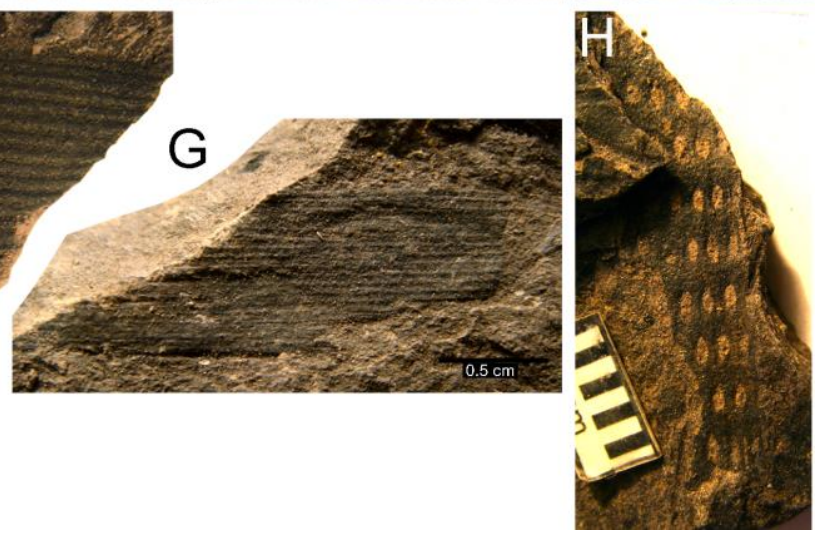

Figure 10 


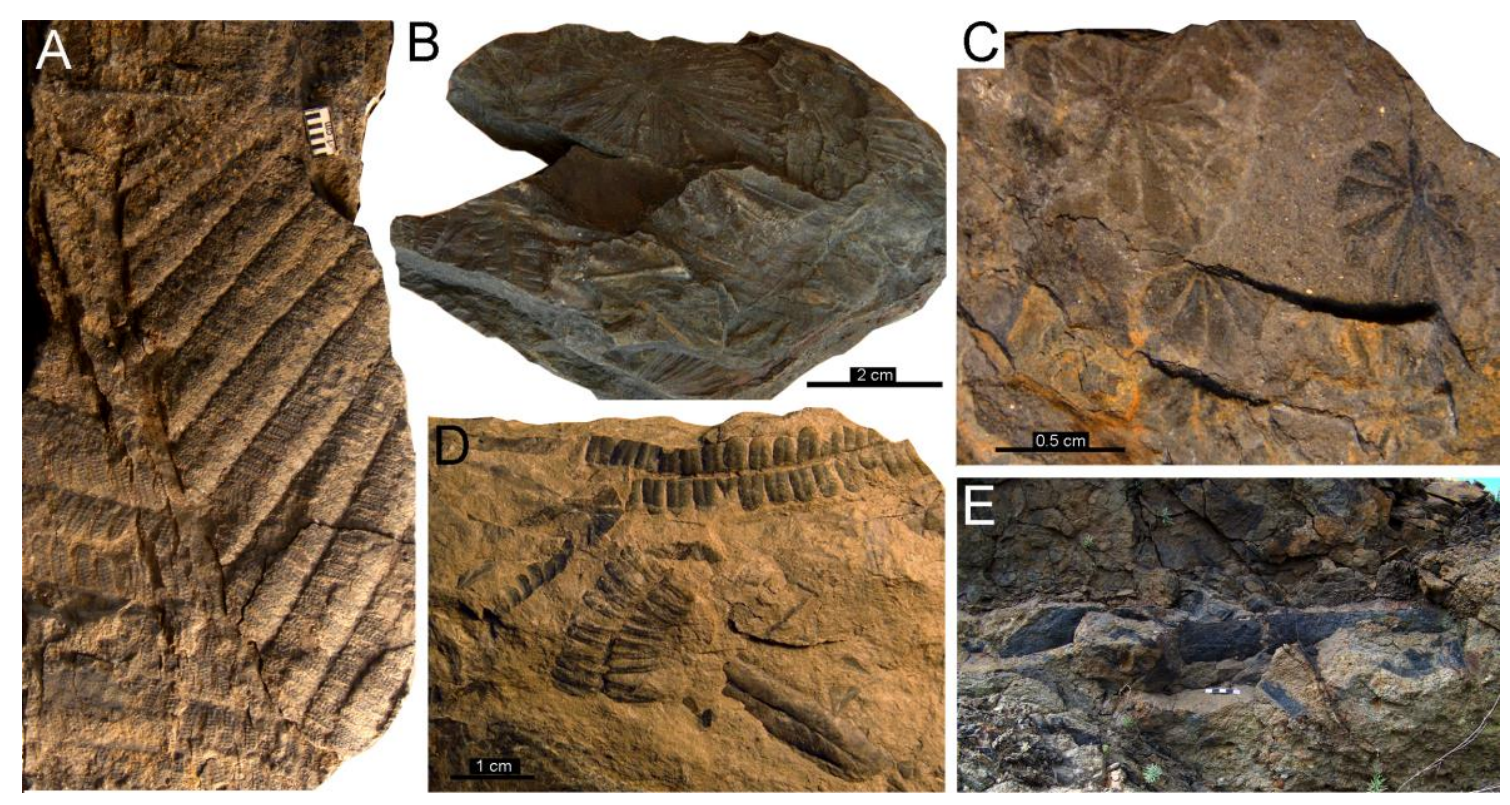

Figure 11 


\section{LES ESGLÉSIES}

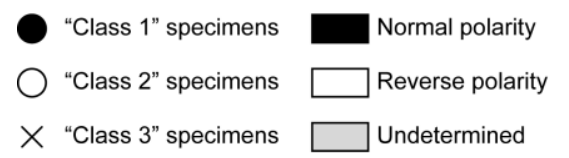

COLL DE SAS
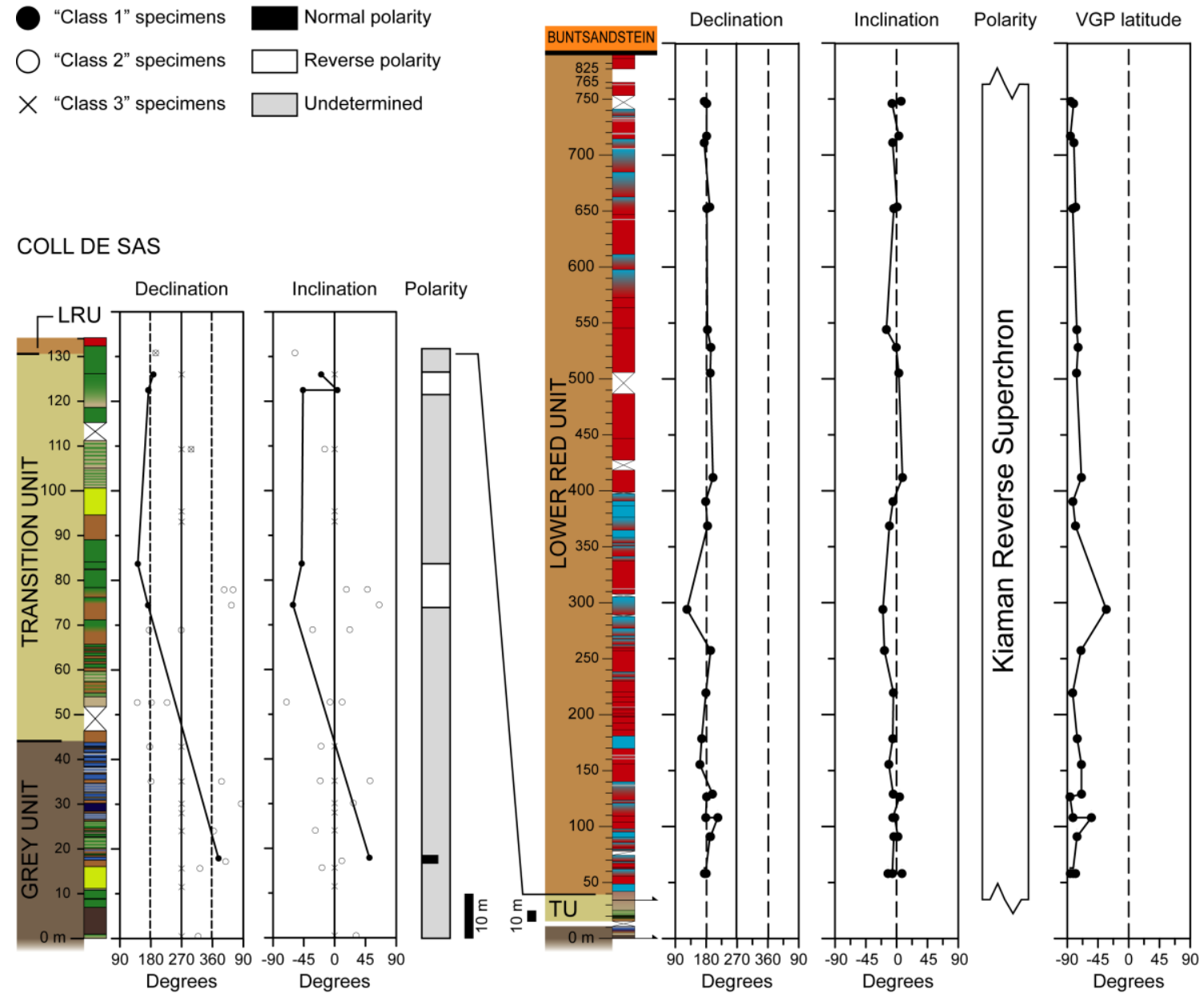

Figure 12 


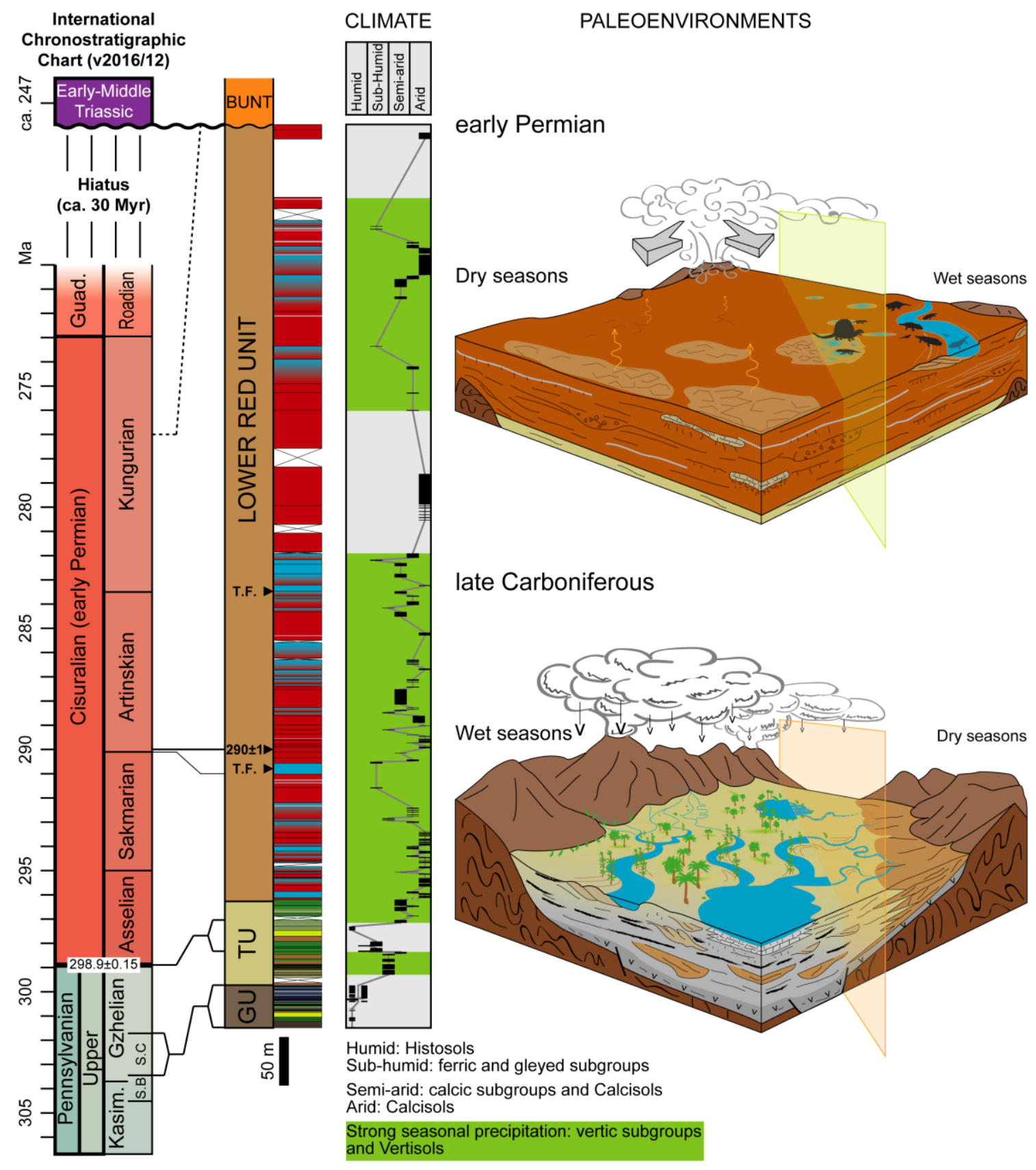

Figure 13 


\section{Research highlights}

- Catalan Pyrenees: $\sim 1000 \mathrm{~m}$ thick Carboniferous-Permian (C-P) terrestrial succession.

- Paleosol succession support the climatic trend throughout the $\mathrm{C}-\mathrm{P}$ transition.

- Central Pangea C-P aridification with climatic fluctuations linked to glaciations. 